\title{
Kamu Hizmetlerinin Sunum ve Finansmanında Kamu Özel İşbirliği Modeli: Avrupa Birliği ve Türkiye
}

\section{Public Private Partnership Model in the Provision and Financing of Public Services: European Union and Turkey}

\author{
Mircan Tokatlıoğlu ${ }^{1}$ \\ Semih Şen ${ }^{2}$
}

RESEARCH

ARTICLE

\author{
ARTICLE INFO \\ Submitted : 25.09.2019 \\ Revised : 07.11.2019 \\ Accepted : 15.11.2019 \\ Available : 30.12 .2019 \\ iThenticate similarity \\ score: $13 \%$ \\ JEL classification: \\ L32, R42, H42 \\ Keywords: \\ Public Services, Public \\ Private Partnerships, \\ PPP, Public Private \\ Sector Collaboration, \\ European Union
}

\section{A B S T R A C T}

The changing role of the state in the economy, especially after the 1990s, has led to the use of more and more public-private partnership (PPP) models as well as traditional methods of providing and financing public services. Public-private partnership, which is an umbrella concept used in the fulfillment of public services in various fields, primarily in infrastructure investments, is becoming a model adopted by the governments of developing countries which can not meet the increasing infrastructure need with limited public resources. Therefore, PPP investments are increasing worldwide. However, this increase brings with it various problems. One of these problems is that it increases risks and uncertainties in terms of public finance, disrupts budget discipline and increases debt stock. For this reason, it is thought to be useful to examine PPP projects. The aim of this study is to evaluate the development of PPP model historically, to determine the place of public services in the methods of presentation and financing and to make a brief evaluation of the applications. Selected experiences are the European Union (EU) and Turkey. Practices of PPP in Turkey, parallel to developments in the world, began in the 1990s. So, we need to look at the practice of other countries in order to evaluate Turkey. Because Turkey is a candidate country to the EU, we need to understand and evaluate the practices of the EU. In this study, it is determined that PPP investments in Turkey an EU has increased.
\end{abstract}

Cite this article as: Tokatlığlu, M. \& Şen, S. (2019). "Kamu Hizmetlerinin Sunum ve Finansmanında Kamu Özel İşbirliği Modeli: Avrupa Birliği ve Türkiye”, International Journal of Public Finance, 4(2), 205-235.

\footnotetext{
${ }^{1}$ Prof. Dr., ORCID: 0000-0001-6358-9498, Bursa Uludağ University, Department of Public Finance, Turkey,miryildiz@uludag.edu.tr

${ }^{2}$ Res. Assist., ORCID: 0000-0001-5020-3998, Bursa Uludağ University, Department of Public Finance, Turkey, semihsen@uludag.edu.tr
} 
Tokatlıŏlu, M. \& Şen, S. (2019). “Kamu Hizmetlerinin Sunum ve Finansmanında Kamu Özel İşbirliği Modeli: Avrupa Birliği ve Türkiye", International Journal of Public Finance, 4(2), 205-235.

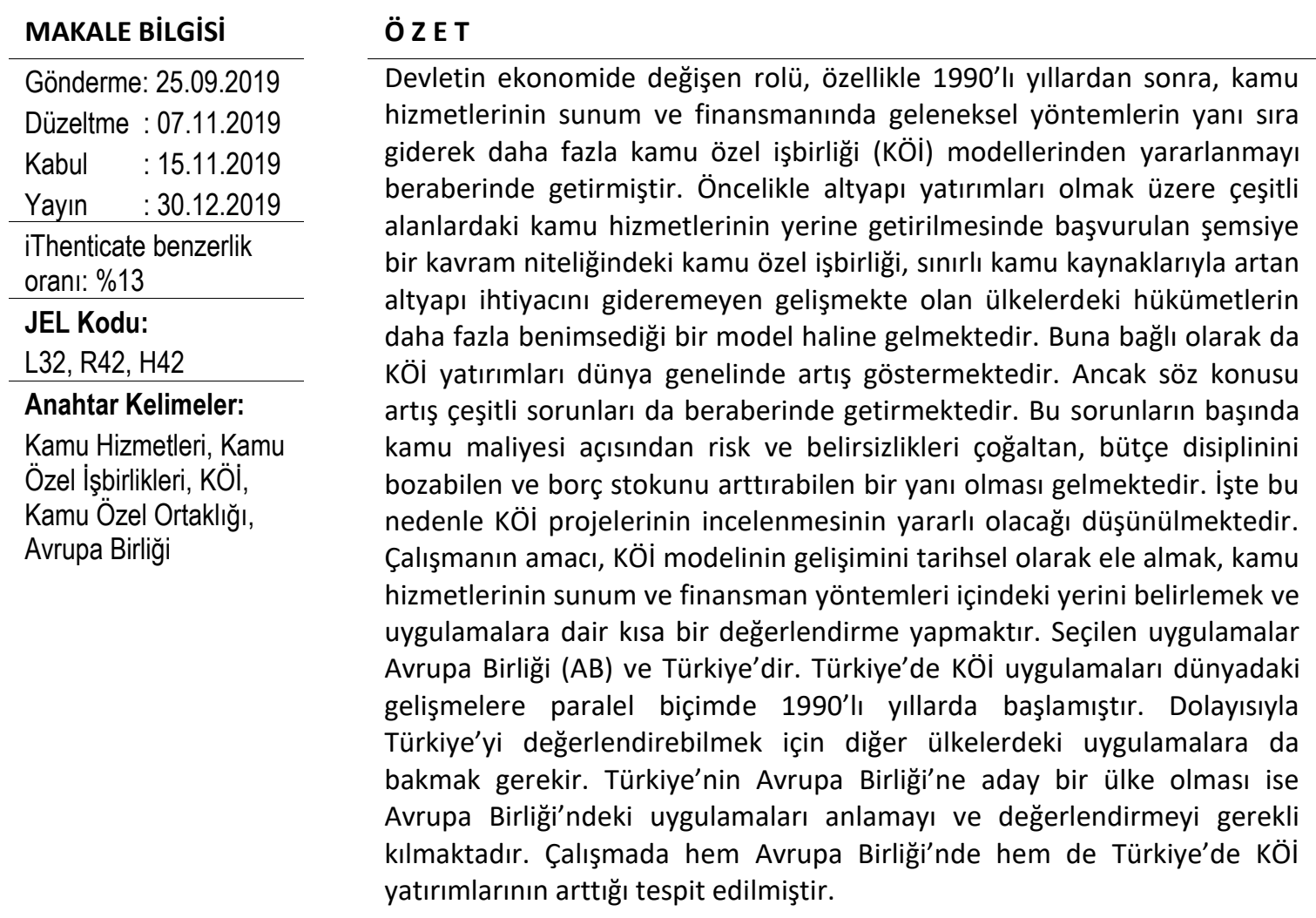

\section{Giriş}

Kamu özel işbirliği veya diğer ifadesiyle kamu özel sektör ortaklığı, günümüzde çok tartışılan ve merak edilen kavramlardan biri haline gelmiştir. Kavramın ekonomik, finansal, hukuki ve sosyal yönleri bulunmaktadır. Dünyada olduğu gibi ülkemizde de, son yıllarda, yapımı devam eden ya da tamamlanmış şehir hastanesi (veya entegre sağlık kampüsü), yol, köprü, havaalanı gibi birçok kamu yatırım projesi kamu özel işbirliği modeli ile gerçekleştirilmektedir. Dolayısıyla bu projeler özellikle büyük kentlerde sunulan kamu hizmetlerinden yararlanan vatandaşların günlük yaşamını doğrudan etkileyen projelerdir. Öte yandan projelerin büyük ölçekli olması ve ciddi miktarda kaynak gerektirmesi, ekonomiye ve bütçeye olan etkilerini önemli hale getirmektedir. Kamu özel işbirliği, kamu ve özel sektör arasında proje bazında risk ve getirilerin paylaşıldığı hukuki bir sözleşmeye dayandığından konunun hukuki yönü de önem kazanmaktadır. Kamu özel işbirliği ile ilgili literatürde daha çok modelin özellikleri, avantajları ve dezavantajları, hukuki yönleri, finansmanı, dünyadaki gelişimi, ülke uygulamaları, Dünya Bankası, Uluslararası Para Fonu ve Avrupa Birliği gibi kuruluşların yaklaşımları üzerinde durulmaktadır. Bu çalışmalarda KÖi'nin bir kamu alımı mı, bir örgütlenme biçimi mi, hizmet sunma yöntemi mi, kamu hizmetlerinin özel kişilere gördürülme yöntemi mi, finansman yöntemi mi olduğu konusunda bir görüş birliği oluşmamıştır. Bunun nedeni başta belirttiğimiz gibi konunun çok yönlü olması ve ekonomideki birçok aktörü doğrudan ilgilendirmesidir. Ancak kamu özel işbirliğinin 
şemsiye niteliğinde bir kavram olduğu ve farklı siyasal ve yönetsel yapılardaki giderek standart hale gelen yapılanma ve işleyiş özellikleriyle bir model haline geldiği yönünde neredeyse bir görüş birliği oluşmaya başlamıştır (Karasu, 2011: 219). Kamu hizmetlerinin KÖi modeli ile özel sektör tarafından gerçekleştirilmesi, hizmetin kamusal niteliğini ortadan kaldırmadığından, bu modeli kamu hizmetlerinin sunum ve finansman yöntemleri içine nasıl dâhil edileceği cevaplanması gereken bir soru olarak ortaya çıkmaktadır. Kamu hizmetlerinin üretim ve sunumunda KÖi modeline başvurulup başvurulmayacağı ve başvurulacaksa bunun miktar ve bileşiminin ne olacağı konusundaki kararlar siyasal süreçte alındığından, konu devletin ekonomiye müdahalesi ve kamu hizmetlerine yaklaşımı ile yakından ilgili olmaktadır. Dolayısıyla bu çalışmada KÖi modeli, kamu maliyesi (veya kamu ekonomisi) bakış açısıyla kamu hizmetlerinin sunum ve finansman yöntemleri içinde geleneksel yöntemlerden ayrı bir başlıkla ele alınmaktadır.

Çalışmanın amacı, devletin ekonomiye müdahalesinin sınırlandırılması düşüncesinin kamu hizmeti anlayışına yansımasıyla gündeme gelen KÖi modelinin tarihsel bir perspektiften ele alınması, KÖi modelinin kamu hizmetlerinin sunum ve finansman yöntemleri içindeki yerinin maliye literatüründen yararlanarak belirlenmesi ve uygulama ile ilgili kısa bir değerlendirmenin yapılmasıdır. Bu değerlendirmede Türkiye ve Avrupa Birliği'ndeki KÖi verileri dikkate alınmaktadır. Çünkü KÖi uygulamaları hem Türkiye hem de Avrupa Birliği'nde aynı dönemlerde yani 1990'lı yıllarda başlamıştır. Diğer taraftan Türkiye'nin Avrupa Birliği'ne aday ülke olduğu düşünüldüğünde, Avrupa Birliği'ndeki gelişmelerin Türkiye'yi yakından ilgilendirdiğini söylemek mümkündür. Bu görüşler çerçevesinde makalenin planı şu şekilde tasarlanmıştır: Girişin ardından, ikinci başlıkta devletin kamu hizmetlerine ilişkin yaklaşımı kuramsal ve tarihsel bir perspektif ile açıklanmaktadır. Üçüncü başlıkta KÖi modelinin kamu hizmetlerinin sunum ve finansman yöntemleri içerisindeki yeri ve türleri, dördüncü başlıkta modelin genel özellikleri, süreci ve finansmanı teorik olarak ifade edilmektedir. Beşinci başlıkta KÖi modelinin Avrupa Birliği ve Türkiye'deki gelişimi ve uygulamaları üzerinde durulmaktadır. Sonuç başlığında ise konu genel olarak değerlendirilmektedir.

\section{Devletin Kamu Hizmetlerine Yaklaşımında Değişim: Kuramsal ve Tarihsel Bir Perspektif}

Devlet, insanların toplum halinde yaşamaları ihtiyacından kaynaklanan yönetim, güvenlik, savunma gibi temel hizmetlerin yerine getirilebilmesi amacıyla oluşturulan bir kurum olarak görülmektedir. Devletin toplumsal intiyaçları gidermek üzere üretip sunduğu hizmetlere de "kamu hizmeti" denmektedir. Devlet kamu hizmetlerini merkezi ve yerel yönetim birimleri aracılığıyla gerçekleştirir. Toplum yararı için gerçekleştirilen kamu hizmetlerinin bazı temel özellikleri bulunmaktadır. Bu özellikler; hizmetin faydasının bölünememesi, hizmet karşılığı bedel ödenmemesi, hizmette birbirine rakip olmama, hukuki zor kullanma ve hizmetin finansmanının vergilerle 
karşılanması olarak ifade edilebilir. Bir kamu hizmetinde bu özelliklerin bir ya da birkaçı birlikte bulunabilir. Devlet piyasa mekanizması yoluyla sunulma imkânı olmayan kamu hizmetlerini bizzat sunar. Diğer bir ifadeyle, piyasa tarafından sağlanamayan, piyasada satılamayan ve pazarlanma imkânı olmayan hizmetleri sunmak devlete düşer. Kamu hizmetlerinin fiyatı ve miktarı piyasa koşullarında belirlenemez (Mutluer, Öner ve Kesik; 2007: 111-114). Bu özelliklere rağmen bir hizmetin kamu hizmeti sayılıp sayılmayacağı, kamu hizmetlerinin neler olacağı ve bunların hangi boyutta yürütüleceği, sahip olunan ekonomik ve mali koşullara göre siyasal iktidarlarca kararlaştırılır. Bir hizmetin kamu hizmeti kapsamına alınması ya da kamu hizmeti kapsamından çıkarılması, temsil ettiği toplum adına siyasal iktidarın yetkisindedir. Bu uygulama anayasal ilke ve koşullar altında gerçekleştirilir (Akdoğan, 1993: 31).

Devletin hangi kamu hizmetlerini sunacağı sadece siyasal bir karara bağlı değildir, tarihsel ve sosyal koşulların yanı sıra devletin ekonomideki rolü ile ilgili iktisadi görüşlerde yaşanan değişim de bunu belirlemektedir. Nitekim 1929 Bunalımı'na kadar olan dönemde devlet, Klasik iktisadın jandarma devlet anlayışının etkisiyle sadece genel nitelikli kamu hizmetlerini (yönetim, adalet, güvenlik, savunma) yerine getirmekteydi. İkinci Dünya Savaşı'ndan sonra Keynesyen iktisat temelli müdahaleci devlet anlayışının yaygınlaşması ve refah devleti uygulamalarına geçilmesiyle devletin ekonomide üstlendiği yeni iktisadi ve sosyal görevler doğrultusunda kamu hizmetlerinin kapsamına ulaşım, enerji, haberleşme, eğitim, sağlık, sosyal güvenlik, toplu konut, toplu taşımacılık gibi ekonomik ve sosyal nitelikli kamu hizmetleri de girmiştir (Tokatlıoğlu, 2005: 3-8).

Ancak 1970'lerde yaşanan stagflasyon krizi ve Keynesyen iktisada yönelik eleştirilerin artması, müdahaleci devlet anlayışının ve bu anlayışın en önemli unsuru olan kamu girişimciliği, kamusal mal ve hizmet üretim biçiminin de sorgulanmasını beraberinde getirmiştir. Bunların kamu maliyesine yük oluşturduğu, kamu maliyesinin bu zararların etkisiyle artan kamu borçlanma ihtiyacının, özel sektör aleyhine kaynak kullanımını bozduğu, enflasyona yol açtığı, faizleri yükselttiği ve büyümeyi yavaşlattığı yönünde (Sönmez, 2018: 59) eleştiriler ortaya çıkmıştır. Bu eleştirilerin kaynağı, neoliberalizm denilen devletin ekonomideki rolünün azaltılması ve piyasa ekonomisine öncelik verilmesi görüşünü savunan iktisatçılardır. Neoliberalizm, özellikle 1980'lerden sonra, kapitalizmin güçlenmesine yol açan sermaye önündeki kısıtların kaldırılması, teknolojideki gelişmeler, Sovyetler Birliği'nde sosyalizmin çökmesi ve piyasa ekonomisine geçiş süreci ve Uluslararası Para Fonu (IMF) ve Dünya Bankası gibi kuruluşların dünya ekonomisini yönlendirmede etkili bir güç haline gelmesi gibi faktörlerin de etkisiyle dünyada yaygın bir kabul görmeye başlamıştır (bkz: Tokatlıoğlu, 2005). Dolayısıyla neoliberal temelli ekonomide serbestleşme, piyasa ekonomisine öncelik verme ve devletin ekonomiye müdahalesini sınırlandırma yönündeki politikalar uygulamaya girdikçe kamu hizmetlerine yönelik yaklaşımlar da Yeni Kamu Yönetimi anlayışı bağlamında değişmeye başlamıştır. Yeni Kamu Yönetimi anlayışı, kamu hizmetini sunma bakımından kamuya ait işletmelerle özel sektöre ait işletmeler arasında hiçbir ayırım yapılamayacağını ve dolayısıyla kamu hizmetlerinin özel sektöre 
sözleşme ile gördürülebileceğini savunmaktadır (Balcı, 2005: 5; Göküş, 2011: 40). Özel sektörün katılımını içeren bu yeni yaklaşımların benimsenmesinde özellikle gelişmekte olan ülkelerdeki kamu idarelerinin mevcut kaynaklarla, artan nüfusun kamu hizmeti taleplerini hem nicelik olarak hem de nitelik olarak karşılamada yetersiz kalmalarının önemli bir rolü olduğu gibi, yeni kamu hizmeti taleplerinin getireceği ek finansman yükünün vergi mükelleflerine yüklenmesinde söz konusu kamu otoritesi ve siyasal iktidarların isteksizliği (Acar, 2012: 3-4) de etkili olmuştur.

Kamu hizmetlerine yönelik yaklaşımdaki bu değişiklik, hizmetin üretimi, sunumu ve yürütülmesinde geleneksel yöntemleri (örneğin emanet gibi) istisna haline getirirken, hizmetin piyasadan teminini esas alan yöntemleri öne çıkarmıştır (Karasu, 2011: 218). Bu bağlamda gelişmiş ve gelişmekte olan birçok ülkede 1980 'li ve 1990 'lı yıllarda yürütülen özelleştirme politikaları, kamu hizmeti alanlarının özel sektöre açılmasını ve daha da ötesinde kamu hizmeti sunan tesislerin ve kamu iktisadi teşebbüslerinin mülkiyetinin özel sektöre satışını içermiştir. Ancak bir süre sonra özelleştirme politikaları sorgulanmaya başlamıştır. $\mathrm{Bu}$ sorgulamanın nedeni özelleştirme uygulanan ülkelerde, kamunun kamusal mal ve hizmetler üzerindeki kontrolünü kaybetmesi, istihdam sorununun artması, özel sektörün daha yüksek maliyetlerle borçlanması nedeniyle sunulan hizmetin fiyatının artması ve özel sektörün işletme maliyetlerini azaltmak için üretilen hizmetin kalitesini düşürmesi gibi olumsuzlukların yaşanmasıdır. Özellikle gelişmekte olan ülkelerdeki özelleştirme politikalarının neoliberal beklentilere cevap vermemesi, uygulamadaki başarısızlıklar, özelleştirme ile ilgili eleştiri ve tartışmaların artmasına yol açmıştır. Bu durum kamu hizmetini sunmak için özelleştirmenin çok etkin bir yol olmadığı düşüncesini beraberinde getirmiş, özelleştirme dili yumuşamış ve özelleştirme yerine "özel sektör katılımcılı̆̆ı", "kamu özel işbirliği" gibi kavramlar öne çıkmıştır (Teker, Teker \& Çimen; 2013: 118; Baylis, 2009: 546; Şahin \& Uysal, 2012: 158).

Kamu özel işbirliği, hem özelleştirmeye yönelik artan eleştiriler hem de kamu borçlanmasına getirilen sınırlamalar nedeniyle özelleştirmeye bir alternatif olarak ortaya atılmıştır (Hemming, 2006: 1-2). Özelleştirmede olduğu gibi, kamu özel işbirliğinde de, önceleri kısmen kamu kesimindeki finansman açıklarını azaltma ve fon kaynaklarını çeşitlendirme gibi nedenler ön plandayken, zaman içinde kamu hizmetlerinde özel sektörün işletme verimlilikleri ve finansal kaynaklarından yararlanma gibi gerekçeler (Çerçi, 2011: 10) de söz konusu olmaya başlamıştır. Günümüzde KÖi modelleri, geniş anlamda altyapı yatırımlarını kapsıyor olsa da içine sağlık, hatta eğitimle ilgili fiziki mekân, "destek hizmet" yatırımları da girmektedir (Sönmez, 2018: 55). Diğer bir ifadeyle KÖi modelleri sosyal ve ekonomik altyapı projelerinde uygulanmakta ve özellikle otoyol, havaalanı, hava trafik kontrol sistemleri, hapishane, hastaneler, okullar, cezaevleri, köprüler, tüneller, hafif raylı sistemler, su ve kanalizasyon tesisleri gibi büyük ölçekli projeleri gerçekleştirmek için dünyanın birçok ülkesinde kullanılmaktadır (Hemming, 2006: 2).

Kamunun özel sektör ile işbirliğine giderek kamu hizmetlerini görmesinin tarihsel kökeni, 17. yüzyıl Kıta Avrupa'sına kadar geriye götürülebilir. Özellikle Fransa 
başta olmak üzere Batı Avrupa ülkelerinde su kanalları, posta hizmetleri, ulaştırma hizmetleri gibi temel bazı hizmetler için kamu özel işbirliği modeli kullanıldığı söylenebilir. Fransa'da 1782 yılında Perier Brothers adlı özel bir firmanın Paris'in içme suyunun sağlanması için yetki alması ve projeyi gerçekleştirmesi KÖi ile ilgili ilk örneklerden biri olarak gösterilmektedir (Kamu Özel İşbirliği Özel ìntisas Komisyonu, 2018: 3-4). Bugünkü anlamda olmasa da kanal ve demiryolu inşası projelerinde kamu özel işbirliği uygulamasının Sanayi Devrimi'nden sonra arttığı, Mısır'daki Süveyş Kanalı'nın da o dönemde kamu özel işbirliği ile yaptırıldığı ifade edilmektedir (Boz, 2013: 280). Bugünkü anlamda ilk KÖi modelinin hayata geçirilmesi İngiltere'de kamu yatırımlarına özel sektörün girişini engelleyen yasanın yürürlükten kaldırılması (Çakır, 2016: 24) ve 1992 yılında “Özel Finansman Girişimi'nin kurulması ile gerçekleştirilmiş ve 1997 yılında İşçi Partisi'nin iktidara gelmesiyle uygulama yaygınlaşmıştır (Chinyio \& Gameson, 2009: 4). Dolayısıyla özelleştirmede olduğu gibi KÖi konusunda da İngiltere'nin bu modelin dünyada yayılmasında etkili bir rol oynadığını söylemek mümkündür.

KÖi modellerinin sadece İngiltere'de değil, diğer Avrupa Birliği ülkelerinde de benimsendiğini ve uygulamaya girdiğini söylemek mümkündür. 1993 yılında yürürlüğe giren Maastricht Antlaşması, üye ülkelerin bütçe açığı ve borçlanmalarına kısıtlama getirdiğinden, ilgili ülkeler kamu yatırımlarının finansmanında özel sektöre yönelme baskısı ile karşı karşıya kalmıştır. Avrupa Birliği de bu uygulamayı teşvik etmiştir. KÖi modelinin gelişmekte olan ülkelerde yaygınlaşmasında ise Dünya Bankası ve IMF'nin önemli bir rolü olduğu söylenebilir. Türkiye'deki KÖi uygulaması da dünyadaki gelişmelere benzer şekilde, 1990'lı yıllardan itibaren enerji ve ulaştırma gibi alanlarda başlamıştır. Modelin geçmişi, devleti ekonomide küçültmek ve kamu yatırımlarının bütçe üzerindeki yükünü azaltmak amacıyla 1980'lerden itibaren yasal altyapısı oluşturulan ve uygulanan yap işlet devret modeline dayandırılabilir. Modelin KÖi adıyla daha gelişkin bir şekilde uygulanması ise 2000'li yıllarda devam etmiştir. 2001 krizi ile derinleşen kamu finansman sorunlarını çözmek üzere uygulamaya giren mali disiplin politikaları, büyük ölçekli kamu yatırımlarının KÖi modeli ile gerçekleştirilmesi için önemli bir gerekçe oluşturmuştur. Ancak günümüzde kÖi uygulaması ile ilgili değerlendirmelerde, kamu yatırımlarının bütçe üzerindeki yükünü azaltmak amacıyla başvurulan KÖi modelinin, bütçede tasarruf sağlamaktan çok, bütçeye yeni maliyetler yükleyebildiği yönünde görüşler ortaya konmaktadır.

\section{Kamu Özel İşbirliği Modelinin Kamu Hizmetlerinin Sunum ve Finansman Yöntemleri İçindeki Yeri ve Türleri}

Kamu özel işbirliği modelinin kamu hizmetlerinin sunum ve finansman yöntemleri içindeki yerini açıklayabilmek için, önce kamu hizmetini tanımlamak, ardından kamu hizmetlerinin üretim ve sunumu konusunda devlet ile özel sektör arasındaki ilişkiyi ortaya koymak gerekir. Kamu hizmeti, devlet tarafından, piyasanın işleyiş ilkelerinden/kurallarından belli ölçüde bağışık kılınarak üstlenilmiş olan, 
toplumsal ihtiyaçları giderecek mal ve hizmet üretimini ifade etmektedir (Karahanoğulları, 2011: 178). Kamu hizmetlerinin üretim ve sunumunda devlet / kamu / idare ile özel sektör arasındaki ilişkiye gelince, bu ilişkinin birkaç noktada ortaya çıktığı söylenebilir. Birincisi devlet, kapitalist ekonomik düzende, hizmeti kendisi üretse bile, üretim için ihtiyaç duyduğu üretim araçlarını/faktörlerini kendisi üretmez, piyasadan yani özel sektörden satın alır. Bu nedenle devletin hizmet üretmek için yaptığı kamu alımları (araç-gereç ve inşaat işleri) özel sektör için kârlı bir faaliyet alanıdır. İkincisi ise devlet, bazen, bazı kamu hizmetlerinin üretimini ya da sunumu veya her ikisini de çeşitli nedenlerle özel sektöre bırakabilir. Bunu geleneksel yöntemler dediğimiz imtiyaz, ruhsat, kiralama sözleşmesi, yönetim sözleşmesi vb. yollara başvurarak yapabilir. Günümüzde bu geleneksel yöntemlerin dışında kamu özel işbirliğine başvurarak da kamu hizmetlerinin özel sektöre gördürülmesi söz konusudur. Kamu hizmetlerinin üretimi ve sunumu dışında finansmanını da dikkate aldığımızda, KÖi modelini içine alan kamu hizmetlerinin sunum ve finansman yöntemlerini, hizmeti üreten ve sunan birimin kamu veya özel sektör kuruluşu olup olmadığı kriterine dayalı olarak altı başlıklı bir sınıflandırma ile açıklamak mümkündür:

i. Kamunun üretip sunduğu hizmetlerin bütçeden finansmanı,

ii. Kamunun üretip sunduğu hizmetlerin yararlananlarca finansmanı,

iii. Özel sektörün üretip kamunun sunduğu hizmetlerin kamusal finansmanı,

iv. Özel sektörün üretip sunduğu hizmetlerin kamusal finansmanı,

v. Gönüllü/kâr amacı gütmeyen kuruluşların kamu hizmetini sunması ve finansmanını sağlaması ve

vi. Özel sektörün üretip sunduğu hizmetlerin kamusal+resmi/resmi olmayan kullanıcı ücretleri ile finansmanıdır.

Sınıflandırmada, Ataay (2007: 77-81)'deki yaklaşım ile Akdemir ve Karakurt (2009: 226)'un sağlık hizmetleri örneği üzerinden ele aldığı hizmet sunum yöntemlerinden yararlanılmıştır. Ayrıca Ataay'ın (2007: 42-45) “kamu hizmetinin doğrudan kamu eliyle görülmesi ile özel sektöre gördürülmesi kriterinin hizmetin kâr amaçlı bir faaliyet olup olmaması yönünde önemli bir farklılık yarattığı; hizmetin finansmanının bütçeden mi yoksa fiyatlandırma ile mi karşılandığı kriterinin de, hizmetin, yararlananların gelir düzeylerine duyarlı olup olmaması noktasında farklılık yarattığı" yönündeki görüşü de önemsenmektedir. Aşağıda söz konusu sınıflandırmaya dayalı kamu hizmeti sunum ve finansman yöntemleri ayrıntıları ile açıklanmaktadır.

\subsection{Kamunun Üretip Sunduğu Hizmetlerin Bütçeden Finansmanı}

Kamu ekonomisinde kamu hizmetlerinin geleneksel üretim ve sunumunun kamu üretici birimlerine (bürokrasi) gördürülmesi emanet yöntemi olarak adlandırılmaktadır. Kamu hizmetinin üretimi için kullanılacak kaynak ilgili kamu biriminin bütçesi tarafından karşılanmakta ve bu hizmet faaliyete geçene kadar bütçe 
ödeneklerinde emanet olarak saklanmaktadır. Tam kamusal özellik gösteren düzen ve güvenlik (yasaların yapılması, polis ve mahkeme hizmetleri) ve savunma gibi kamu hizmetlerinin özel sektöre emanet yöntemi ile gördürülmesi söz konusu değildir. Hizmetin niteliği ve içeriğinin denetimi, üretimin kamu idaresi tarafından yapılmasını gerektirmektedir (Bulutoğlu, 2008: 147; Çakır, 2016: 29; Erdem, 2015: 5). Kamu hizmetinin kamu eliyle görülüp bütçeden finanse edilmesinin en önemli özelliği, hizmetin kâr amaçlı olmamasıdır. Bütçeden finansman, tüm toplum bireylerinin ödeme gücünün göstergeleri olan gelir, tüketim ve servetleri ile orantılı olarak ödediği vergiler ile kamu hizmetinin finansmanına katılımını ifade etmektedir. Bu finansman yöntemi kamu hizmetlerinin sosyal devlet anlayışına uygun bir yaklaşımla sunulmasına imkân vermektedir (Ataay, 2007: 43).

\subsection{Kamunun Üretip Sunduğu Hizmetlerin Yararlananlarca Finansmanı}

Kamunun üretip sunduğu hizmetlerin yararlananlarca finansmanı, kamu hizmetlerinin kamusal niteliği gereği, hizmetin faydası ve maliyetlerine tam karşılık gelmeyen bir bedel (hizmetin fiyatı) alınması esasına dayanmaktadır. Genel bütçe ile finanse edilen kamu hizmetleri için fiyatlandırma söz konusu değildir. Fiyatlandırma daha çok piyasa malları sunan kamu işletmeleri ve elektrik, ulaştırma, haberleşme gibi doğal tekel niteliği taşıyan kamu hizmet alanlarında uygulanmaktadır. Bunun yanı sıra büyük ölçüde genel bütçeden finanse edilen kamusal eğitim ve sağlık hizmetleri de fiyatlama yapılabilen kamu hizmetleri arasında yer alabilmektedir. Fiyatlandırmanın amacı, kâr elde etmek değil, kamu hizmetinin maliyetini, en azından bir bölümünü karşılamaktır (Kirmanoğlu, 2019: 178-179). Yükseköğretim hizmetlerinden harç alınması, paralı yol uygulaması, sağlık hizmetlerinde reçete bedellerine katılma payı vb. uygulamalar bu yöntemin değişik örnekleridir (Aktan, 1987: 118).

\section{3. Özel Sektörün Üretip Kamunun Sunduğu Hizmetlerin Kamusal Finansmanı}

Kamu hizmetlerinin özel sektörden "satın alma" yoluyla teminine dayanan bu yöntemde, hizmetin finansmanı bütçeden ya da sosyal güvenlik kaynakları gibi kamusal fonlardan karşılanmaktadır. Bireyler hizmetin finansmanına ödedikleri vergiler ya da sosyal güvenlik primleri ile katılmakla birlikte, özel sektöre hizmetin maliyetinin yanı sıra belirli bir kâr da ödediğinden, kamu hizmeti kâr amaçlı bir faaliyete dönüşmekte ve özel sektöre kaynak aktarımının aracı haline gelmektedir (Ataay, 2007: 45-46). Kamu hizmetlerinin özel sektör tarafından üretilmesi ve sunumunun gerçekleştirilmesi için, ilgili kamu idaresinin özel sektörden mal, hizmet ve yapım işlerini satın alması literatürde "ihale yöntemi" olarak adlandırılmaktadır (Edizdoğan \& Çetinkaya, 2010: 289). Ihale yönteminde hizmetin üretimi özel firma tarafından gerçekleştirilirken, hizmet sunumuna yönelik tüm yükümlülükler devlette kalmaktadır. Devlet sermayedar olarak, özel firma tarafından üretilen mal ve hizmetlerin türü ve kalitesine ilişkin 
kararları alma ve gerekli politikaları uygulama yetkisine sahip olmaktadır (Aktan \& Dileyici, 2005: 53).

Bazı kamu hizmetlerinde ihale yöntemine başvurulamaz, hizmetin niteliği ve içeriğinin denetimi, üretimin devlet dairesince yapılmasını gerektirir. Yukarıda belirttiğimiz emanet yöntemi ile görülmesi gereken kamu hizmet türleri aynı zamanda ihale yöntemiyle piyasa firmalarına bırakılamayacak hizmetlerdir (savunma, güvenlik, genel idare vb). Buna karşılık özel fayda sağlayan pazarlanabilir, dolayısıyla fiyatlandırılabilir bazı eğitim, sağlık gibi bazı kamu hizmetlerini ise devlet ihale yoluyla özel sektöre yaptırabilir (Bulutoğlu, 2008: 147). Hizmetin niteliğinin sürekli olarak denetiminin gerekli olmadığı hallerde ihale yöntemi yaygın biçimde kullanılabilir. Örneğin karayolu, köprü, liman gibi bayındılık işlerinde, kamu idaresi ürünün niteliklerini şartnameyi hazırlayarak belirttiğinde, teslim aşamasında hizmetin şartnameye uygun olup olmadığını fazla bir maliyete katlanmadan denetleyebilir (Bulutoğlu, 2008: 147).

\section{4. Özel Sektörün Üretip Sunduğu Hizmetlerin Kamusal Finansmanı}

Burada sübvansiyon ve kupon yöntemi olmak üzere iki ayrı yöntemden söz etmek mümkünüdür. Sübvansiyon yöntemi, bir kamu hizmetinin tedarik edilmesi ya da üretiminde değişiklik meydan getirmek için doğrudan veya dolaylı olarak mali destek sağlanmasını içermektedir. Doğrudan sübvansiyonlar yardım ve bütçesel destek, dolaylı sübvansiyonlar ise vergiden muaf tutmak ve kamu garantisi gibi biçimlerde olabilmektedir (Akdemir \& Karakurt,2009: 228). Kupon yöntemi ise devletin düşük gelirli bireylere eğitim, sağlık, ulaşım, kreş vb. mal ve hizmetleri doğrudan sunmak yerine, hizmetin bedelini kapsayan bir kupon vererek, hizmetin özel sektörden teminini olanaklı hale getirmesidir (Tokatlıoğlu, 2005: 104-105). Bu yöntemde devlet kamu hizmetinin kullanıcılarına kupon vererek, üretimin piyasa şartlarında yapılmasını ve dolayısıyla piyasadaki rekabetin sağlayacağı etkinlikten yararlanmayı hedeflemektedir. Böylece kamu hizmetinin arz tarafı özel finansmanla sağlanırken, talep tarafı kamusal finansman ile karşılanmaktadır (Kirmanoğlu, 2019: 194).

\subsection{Gönüllü / Kâr Amacı Gütmeyen Kuruluşların Kamu Hizmeti Sunması ve Finansmanını Sağlaması}

Bazı kamu hizmetlerinin görülmesinde gönüllü/kâr amacı gütmeyen kuruluşlar (hayırsever kuruluşlar, vakıflar, dernekler, dini organizasyonlar vb.) tarafından sunulması ve finansmanının sağlanması söz konusu olabilir. Bu kamu hizmetlerine örnek olarak okul ve hastane yapımı, öğrencilere eğitim ve araştırma bursu verilmesi, kültürel ve sanatsal faaliyetler düzenlenmesi (müzeler, özel kütüphaneler, sanat galerileri, senfoni orkestrası kurulması vb.), çevre koruma hizmetleri, kan bankaları kreş vb. verilebilir (Tokatlıoğlu, 2005: 105-106). 
Tokatlıŏlu, M. \& Şen, S. (2019). “Kamu Hizmetlerinin Sunum ve Finansmanında Kamu Özel İşbirliği Modeli: Avrupa Birliği ve Türkiye", International Journal of Public Finance, 4(2), 205-235.

\section{6. Özel Sektörün Üretip Sunduğu Hizmetlerin Kamusal+Resmi/Resmi Olmayan Kullanıcı Ücretleri İle Finansmanı}

Devlet, bazı kamu hizmetlerinin özel sektör eliyle üretilip sunulması ve hizmet finansmanının hizmetten yararlananların karşılığında ödediği bedelle sağlanması için düzenlemeler yapabilir. Kamu hizmetini yerine getiren özel sektör kuruluşu bu faaliyeti kâr amacıyla yapacağından, hizmetin fiyatı, maliyet artı makul düzeyde bir kârı içerecektir. Ancak devlet özel sektör kuruluşunun kârının aşırıya kaçmaması ve makul düzeyde tutulması için fiyatları belirleme yetkisini elinde bulundurmak durumundadır (Ataay, 2007: 79-80). Özel sektörün üretip sunduğu hizmetlerin yararlananlarca finansmanını, kamu hizmetlerinin özel sektöre gördürülmesinin geleneksel yöntemleri ve 1990 lardan sonra dünyada yaygınlaşmaya başlayan ve kamu hizmetlerinin kamu ile özel sektörün işbirliğine dayalı olarak görüldüğü modeller, yani kamu özel işbirliği modelleri olarak iki ayrı alt başlıkta açıklamak mümkündür.

\subsubsection{Geleneksel Yöntemler}

Kamu hizmetlerinin özel sektör eliyle üretilip sunulması ve yararlananların ödediği bedellerle finansmanının geleneksel yöntemlerini, "imtiyaz", "ruhsat", "kiralama sözleşmesi", "yönetim sözleşmesi", "müşterek emanet" ve "iltizam" olarak ifade etmek mümkündür. Bu yöntemleri kısaca açıklamak gerekirse şunlar söylenebilir:

İmtiyaz yöntemi, doğal tekel niteliği taşıyan su, gaz, elektrik, metro vb. toplu taşıma, kanalizasyon gibi belediyelerin sunduğu yerel kamu hizmetlerinde, hizmet sunma hakkının özel bir firmaya verilmesidir. Bazen belli bir kamu hizmet alanında alt birimlere, örneğin elektrik hizmetlerinde elektrik üretimi, iletimi ve dağıtımı için ayrı ayrı imtiyazlar verilebilmektedir. İmtiyaz hakkını elde eden özel firmanın hizmetinden yararlananlar ödemeyi doğrudan hizmeti sunan özel firmaya yapmaktadırlar (Akıllı, 2013: 95; Aktan \& Dileyici, 2005: 55-57). Bu yöntemde kamu idaresi (imtiyazı veren) ile özel kişi (imtiyazlı) arasında uzun süreli bir (idari) sözleşme yapılmaktadır. Bu sözleşme uyarınca belli bir kamu hizmetinin, sermayesi, kârı, hasar ve zararı özel kesime ait olmak üzere özel kişilerce kurulması ve işletilmesi ya da daha önce kurulmuş bulunan hizmetin sadece işletilmesi söz konusudur (Akıllı, 2013: 94). Burada hizmetten alınacak ücret, hizmetten yararlananların ödeme gücü de göz önünde bulundurularak kamu idaresi tarafından belirlenmektedir. İmtiyaz yönteminde temel nokta pazarlık sürecidir. İmtiyaz, pazarlık ile sözleşmede nitelikleri belirtilen mal ya da hizmeti en düşük bedel ile piyasaya sunmayı kabul eden firmaya verilmelidir.

Ruhsat yöntemi, doğal tekel niteliğinde olmayan ve özel kişiye tekel kurma hakkı tanınmayan bir kamu hizmetinin kamu idaresi tarafından verilen izin üzerine özel kişilere gördürülmesidir (Ataay, 2007: 47; Akıllı, 2013: 94). Ruhsat yönteminde, kamu idaresi ile özel kişi ve kuruluş arasında bir sözleşme olmamakta, kamu hizmetinin sunum maliyeti üzerine yüksek bir kâr konulmaması ve bunun ilgili kamu idaresi tarafından denetlenmesi kanuna dayanarak yapılmaktadır (Erdem, 2015: 6-7). 
Kiralama sözleşmesi yöntemi, özel sektörün genellikle kamu kesimine ait hizmet tesislerini kullanmak için bir ücret karşılığında kiralaması, tesisi yönetme ve işletme için sorumluluk alması ve bu amaçla kiralama sözleşmesi yapılmasıdır. Özel sektörün bu sözleşmeye dayalı olarak üretip sunduğu kamu hizmetinden gelir elde etme hakkı bulunmaktadır. Kamu kesimi artık kiralama yapılan alanda faaliyette bulunmadığından özel sektör tüm ticari risklere katlanmak zorundadır (Akdemir \& Karakurt, 2009: 227).

Yönetim sözleşmesi yöntemi, özel sektörün bir sözleşme ile mülkiyeti kamu kesimine ait hizmet tesislerinin ücret karşılığında yönetme sorumluluğunu üstlenmesidir. Bu yöntemde özel sektöre yönetim alanında geniş yetkiler verilirken özel sektörün finansal bir yükümlük altına girmesi ya da yürüttüğü faaliyetin kârlılığına bağlı olarak kendisine bir ödeme yapılması söz konusu değildir. Kamu kesimi tüm ticari riski taşımaya devam etmekte ve çalışma sermayesi ile borçla finansmandan sorumlu olmaktadır. Bu yöntemin avantajı, mülkiyetin devlette kalması, belli derecede de olsa denetimin sürdürülebilmesi ve özel sektörün yönetim ve diğer becerilerinin kamu kesimine aktarılması ve böylece kamu hizmetinde verimlilik ve kârlılığı arttırma imkanını getirmesi olarak görülmektedir (Akdemir \& Karakurt, 2009: 227). Ancak yönetim, mülk sahibi kadar özen göstermeyebilir ve yönetimin muhasebe ve denetim ölçütleri yeterli değilse, değerlendirilmesi güç olabilir (Kepenek, 1990: 155).

Müşterek emanet yöntemi, bir kamu hizmetinin masrafları, hasar ve zararı kamu idaresine ait olmak üzere, gelir üzerinden belli bir pay veya götürü bir ücret karşılığı özel bir kişiye veya firmaya gördürülmesidir. İltizam yöntemi ise müşterek emanet yönteminin mali konularda uygulanma biçimi olup, mültezim adı verilen bir özel kişiye bir bedel karşılığında bir kamu hizmetinin gördürülmesini ifade etmektedir (Akıllı, 2013: 94). Hizmetin karşılığı özel kişi ya da kuruluşa götürü olarak verilmektedir. Günümüzde iltizam usulü kullanılmamaktadır (Keskin, 2005: 47).

\subsubsection{Kamu Özel İşbirliği Modelleri}

\subsubsection{Kamu Özel İşbirliği Kavramı}

Kamu özel işbirliği, kamu hizmeti sunum ve finansmanında, bir ucunda kamu mülkiyeti altında geleneksel kamu mal ve hizmet tedarikinin yer aldığı, diğer ucunda ise özelleştirmenin bulunduğu yelpazede hizmetin tümüyle özel sektör eliyle gerçekleştirilip finanse edildiği alternatif uygulamalardan biri olarak görülmektedir. Bu nedenle devlet ve özel sektörün birlikte katılımını içeren tüm kamu mal ve hizmet sağlama modellerinin bir üst kavramı olarak değerlendirilebilir (Kesik, 2012; Çerçi, 2011: 13; Güzelsarı, 2013: 313; ayrıca bkz: Kovancılar, Miynat \& Bursalıoğlu, 2007: 197). Literatürde kavramın adı konusunda bir çeşitlilik söz konusudur. İngiltere'de "Özel Finansman Girişimi (PFI)", Amerika Birleşik Devletleri (ABD)'nde "Kamu Özel Ortaklığı" (PPP), Türkiye'de ise "Kamu Özel Sektör Ortaklığı", "Kamu Özel Sektör İşbirliği", "Kamu Özel Sektör Ortak Girişimciliği", "Kamu Özel İşbirliği" kavramları 
kullanılmaktadır. Resmi raporlarda "Kamu Özel İşbirliği" kavramı kullanıldığından bu çalışmada da aynı kavram benimsenmiştir.

Kalkınma Bakanlığı (bugünkü adıyla Strateji ve Bütçe Başkanlığı), kamu özel işbirliğini "bir sözleşmeye dayalı olarak, yatırım ve hizmetlerin, projeye yönelik maliyet, risk ve getirilerinin, kamu ve özel sektör arasında dengeli bir şekilde paylaşılması yoluyla gerçekleştirilmesi olarak tanımlamıştır T.C. Kalkınma Bakanlığı (2015). ABD Genel Muhasebe Ofisi'nin tanımlaması ise "kamu özel ortaklığı, kamu hizmetini sunan bir sistem ya da tesisi kısmen veya tamamen yenilemek, inşa etmek, işletmek, bakımını sağlamak ve/veya yönetmek için kamu ve özel sektör ortakları arasında oluşturulmuş sözleşmeye dayalı anlaşma" şeklindedir (Şahin \& Uysal, 2008: 12-13). Dünya Bankası, KÖi modelini, risk ve yönetim sorumluluğu özel sektöre ait olmak üzere kamusal mal ve hizmet üretimi ve sunumunun sağlanması amacıyla, hem kamu idaresinin hem özel sektör kuruluşunun uzun dönemli sorumluluk üstlendiği sözleşmeler olarak tanımlamaktadır (https://ppiaf.org/about-us). Bir başka tanıma göre ise, "kamu ve özel sektör ortaklığı, her bir ortağın uzmanlığını alarak kaynakların, risklerin ve getirilerin uygun şekilde tahsis edilmesi yoluyla kamusal ihtiyaçları en iyi şekilde karşılayan kamu ve özel sektör birimlerince yapılan ortak bir girişim modelidir" (Köstekçi, 2017: 312).

\subsubsection{Kamu Özel İ̧̧birliği Türleri}

Kamu özel işbirliği modelleri çeşitli şekillerde uygulanabilmektedir. Aşağıda bu modellerden sadece yap işlet devret, yap işlet, yap kirala devret, işletme hakkı devri üzerinde durulacaktır. Bunların dışındaki modeller; yap devret işlet, yap işlet sahip ol devret, tasarla yap, tasarla yap işlet, tasarla yap finanse et işlet, ek yatırım yap tüm tesisi işlet ek yatırıma sahip ol, geliştir işlet ve işletme bakım modeli olarak ifade edilebilir (bkz: Grimsey \& Lewis, 2004: 10-12; Güzelsarı, 2013: 327-328; Köstekçi, 2017: 319-321).

Yap işlet devret, bir özel sektör firmasının belirli bir dönem için sözleşmeyle bir kuruluşu veya tesisi inşa etme ve işletme imtiyazını elde etmesi ve söz konusu dönemin sonunda kuruluşu devlete devretmesidir. Alt yapı hizmetlerinin hem sunumu hem de finansmanında özel sektörden yararlanmayı amaçlayan bu yöntemde devletin altyapı hizmetlerine yatırım yapması yerine bu hizmetlerin finansmanı özel sektörden sağlanmaktadır (Aktan \& Dileyici, 2005: 54-55). Yap işlet devret sözleşmeleri, ilk olarak Türkiye'de geliştirilmiştir (Yescombe, 2007: 7-8). Devlet bu modelle ayrıca yabancı sermayenin katkısını da amaçlamaktadır. Böylelikle büyük elektrik santralleri, barajlar, hava alanları, metrolar, elektrik enerji dağıtımı, şehir suyu tesisi, toplu taşımacılık ve bazı karayollarının yapımı gibi projelerin bütçe kaynaklarına ağır bir yük getirmeden gerçekleştirilmesi imkanı ortaya çıkmaktadır. Kamu yararı özelliği ağır basan söz konusu alt yapı yatırımları için oluşturulan yap işlet devret sözleşmelerinin bir tarafında kamu idaresi diğer tarafında ise yerli ya da yabancı veya her ikisinin oluşturduğu konsorsiyumlar ve iş ortaklıkları (joint venture) bulunmaktadır. Yap işlet devret 
modelinin ekonomik açıdan faydası kamu idaresinin yatırıma yönelik finansman yükünü azaltması olarak görülürken; sakıncası kamusal özelliği ağır basan yatırımların ticari kârlılık koşullarında sunulması olarak görülmektedir. Yap işlet devret yöntemiyle üretilip sunulan hizmetler yararlananlara kamu eliyle üretilip sunulması durumuna göre daha pahalıya gelmektedir (Şenyüz, 1996: 4-5).

Yap işlet devret modelinin tercih edilmesinin en önemli nedeni, devletin bütçe hesaplarında önemli bir yer tutacak büyük ölçekli kamu yatırımlarının finansman yükünün özel sektöre aktarılmasıdır (Kılıçaslan, 2017: 38). Özel sektörün yatırımı kamuya göre daha etkin ve verimli gerçekleştireceği de varsayılır. Büyük ölçekli yatırımların finansmanına yabancı sermayenin katılımının teşvik edilmesi halinde, sadece finansman değil, yurt dışındaki teknolojiyi de transfer etme imkânı ortaya çıkmaktadır (Tokatlıŏlu, 2017: 31). Yap işlet devret modeli ile finansman, üretilecek kamu hizmetinin yatırım bedelinin (elde edilecek kâr dahil) özel sektör şirketine, şirketin işletme süresi içerisinde ürettiği mal veya hizmetin idare veya hizmetten yararlananlarca satın alınması suretiyle ödenmesini ifade etmektedir (Yerlikaya, 2003: 422).

Yap işlet, "kamu ile özel sektör arasında yapılacak bir sözleşme çerçevesinde, bir tesisin özel sektör tarafından tasarlandığı, finanse edilerek yapıldığı, işletildiği ve tesisin mülkiyetinin özel sektörde kaldığı modeldir" (Güzelsarı, 2013: 327). Ülkemizde elektrik enerjisi üretiminde uygulanmıştır. Uygulamaya göre modelde, özel sektöre mülkiyetleri kendine ait olmak üzere termik santral kurma ve işletme izni verilmekte, üretilen elektriği devlet satın almaktadır. Sözleşme bitiminde ise tesis özel sektörde kalmaktadır (T.C. Kalkınma Bakanlığı, 2016: 14).

Yap kirala devret, "kamu ile özel sektör arasında yapılan bir sözleşme ile bir tesisin özel sektör tarafından tasarlandığı, finanse edilerek yapıldığı, belirli bir süre için idareye kiralandığı, gerekli hallerde yatırım kapsamındaki mal ve hizmet üretim birimlerinin kısmen veya tamamen yapımcı tarafından işletildiği ve sözleşmede yer alıyorsa tesisin mülkiyetinin kira dönemi sonunda, kamuya geçtiği modeldir" (Güzelsarı, 2013: 327). Yap kirala devret modeli, Türkiye'de olduğu gibi, daha çok sağlık sektöründe şehir hastaneleri yatırımlarında tercih edilmektedir. Şehir hastaneleri uygulamasında yap kirala devret, ihale ile belirlenen şirket ya da şirket ortaklığının, bedelsiz tahsis edilen Hazine arazisi üzerinde, finansmanını -kamusal garantiler kolaylığı altında- sağlayarak inşa edip tamamlayacağı tam teşekküllü bir hastaneye, Sağlık Bakanlığı'nın -en az- 25 yıl süreyle kiracı olmasını ifade etmektedir (Toker, 2018: 250). Yap kirala devret yöntemi ile gerçekleştirilen sağlık yatırımlarında risk, devlet ve özel sektör arasında paylaşılmaktadır. Yatırım özel sektör tarafından tamamlandıktan sonra sağlık hizmetinin sunumu ise devlet tarafından sağlanmaktadır. Özel sektör tıbbi destek (görüntüleme, laboratuvar ve diğer tıbbi destek hizmetleri) ve tıbbi olmayan hizmetlerin sunumu ve ticari alanların işletilmesinden sorumlu olmaktadır. Sağlık tesisinin işletme süresi boyunca devlet, özel sektör ortağına bir "bedel" ya da "kira" ödemektedir (Kulaksız \& Küçükkocaoğlu, 2019: 198). 
İşletme hakkı devri, devletin, bir sözleşmeye dayanarak, mevcut bir tesisin işletme hakkını belirli bir süreliğine özel sektöre devrettiği kamu özle işbirliği modelidir (T.C. Kalkınma Bakanlığı, 2016: 14). Bu modelde, mülkiyeti kamuda kalmak üzere, ilgili kamu idaresinin aktifindeki mal ve hizmet üretim birimlerinin işletilmesi tam olarak veya kısmen, bir bedel karşılığında belli bir süreliğine özel sektöre bırakılmaktadır (Güzelsarı, 2013: 327). Burada sadece kamu hizmeti niteliği taşıyan mal ve hizmetlerin değil, aynı zamanda doğal kaynakların ve kamu hizmeti konusu oluşturmayan mal ve hizmet üretim birimlerinin de işletme haklarının devredilmesi söz konusudur (Ayanoğlu, 2007: 6'dan aktaran Kılıçaslan, 2017: 39).

\section{KÖi Modelinin Özellikleri, Süreci, Faydaları ve Finansmanı}

\subsection{KÖi Modelinin Özellikleri}

Kamu özel işbirliği modelinde, kamu sektörü, özel sektör ile bir altyapı projesi veya bir kamu hizmetinin sunumu amacıyla başta finansman olmak üzere yapım, işletim, yenileme ve onarım gibi alanlarda işbirliğine gitmektedir. Burada kamu sektörü özel sektörden yararlanırken, yatııımın riskini de paylaşmaktadır. Ancak hizmet üretimi ve sunumunda kamusal özellik değil, özel sektör mantığı ön planda olmaktadır (Kovancılar, Miynat \& Bursalıoğlu, 2007: 202). Gelişmiş ve gelişmekte olan ülkeler açısından kamu ve özel sektör arasında bu işbirliğini gerekli kılan ya da ortaya çıkaran faktörler çeşitlidir. Bu faktörleri kamu kesiminin finansman ihtiyacı temelinde finansman kaynaklarının çeşitlendirilmesi, kamu borçlarının azaltılması, sermaye harcamalarının artırılması, işlem maliyetlerinin azaltılması, hizmet maliyetlerinin düşürülmesi, yatırım ve hizmetlerde tasarruf sağlanması, kamu ile özel kesim arasında dengeli bir risk dağılımının sağlanması, bütçe dengesinin sağlanması vb. olarak ifade etmek mümkündür (Güzelsarı, 2013: 313).

\subsection{Kamu Özel İşbirliği Süreci}

Kamu yatırımlarında kamu ve özel sektörün işbirliğine gitmesi; proje kapsamının belirlenmesi, proje stratejisinin oluşturulması, seçim süreci, müzakereler, sözleşme yapılması ve hizmet sunumunun başlaması aşamalarını içermektedir. Proje kapsamının belirlenmesinde, projenin hangi ihtiyaca cevap vereceğinin belirlenmesi ve projeden beklenen faydaların tespit edilmesi söz konusudur. Stratejinin oluşturulması aşamasında, ihale grubunun oluşturulması ve ihale çıktı şartnamesinin düzenlenmesi gibi ihale ile ilgili çalışmalar yapılmakta ve riskler belirlenmektedir. Seçim süreci, proje ile ilgilenen firmaların tekliflerinin alınması, firmaların ön koşulları sağlayıp sağlayamadığının incelenmesi ve ön elemeyi geçen firmaların tespit edilmesi aşamasıdır. Müzakere aşamasında ise proje kapsamında sağlanması talep edilen hizmete ilişkin ön elemeyi geçen firmalarla müzakere yürütülmektedir. Tespit edilen sözleşme şartları çerçevesinde değerlendirme yapılmakta ve ihaleyi kazanan firma 
belirlenmektedir. Sözleşme yapılması aşamasında, ihaleyi kazanan firma ile yapılacak sözleşmede önemli risklerin transferi, paranın iyi bir şekilde değerlendirilmesi ve ödenebilirlik kriterleri dikkate alınmaktadır. Son aşamada ise hizmetin ilgili özel kesim kuruluşu tarafından sunumu gerekmektedir (Kovancılar, Miynat \& Bursalıoğlu, 2007: 202). Buna göre KÖi modeliyle bir kamu hizmeti sağlanması sürecinin geleneksel tedarik yöntemlerine göre daha karmaşık, daha uzun vadeli ve çok taraflı olduğu ve modellerin tasarımı ve uygulanmasında tarafların getiri beklentilerinin yanı sıra risklerin nasıl paylaşıldığı da önemli olmaktadır. Sonuçta KÖi, kamu ile özel sektör arasında yapılan, ticari finansal analiz ile toplumsal fayda-maliyet analizi arasındaki farkın kamu sektörü tarafından kapatıldığı bir iş ortaklığı sözleşmesi olarak ortaya çıkmaktadır (Çerçi, 2011: 16).

\subsection{KÖi Modelinden Beklenen Faydalar}

Kamu hizmetlerinin sunum ve finansman yöntemi olarak KÖi modelinin hükümetler tarafından benimsemesinde, bu modelin sağlayabileceği çeşitli iktisadi, mali ve sosyal nitelikli fayda beklentileri önemli bir rol oynamaktadır. Bu faydalardan çalışmanın kapsamını ilgilendiren belli başlı olanları üç noktada ifade edilebilir:

KÖi modelinden beklenen birinci fayda, kamu yatırım projelerinde kamu kesimi ile özel kesim arasındaki risk paylaşımının adil yapıldığı ve etkin rekabetçi piyasa şartlarının sağlandığı varsayımıyla maliyet minimizasyonunun gerçekleşeceği ve optimum kamusal hizmet üretim düzeyinin tesis edileceği beklentisidir. Bilhassa bu konuda özel kesimin yönetim becerilerinin kamu kesimine görece daha üstün olduğu kabul edilmekte ve böylelikle üretilen kamusal hizmetin sunum kalitesinin de iyileşeceği tahmin edilmektedir (Kılıçaslan, 2017: 46; Şahin \& Uysal, 2008: 39).

Beklenen ikinci fayda, KÖi modeli ile özel kesimin kaynaklarına başvurmakla, kamu kesiminin bütçe imkânları genişlemekte ve böylelikle farklı kamusal ihtiyaçlar için ek kaynak yaratılmış olmaktadır (Asian Development Bank, 2008: 3). Çünkü hükümetler, uzun vadede borçlanma gibi doğrudan kamu yükümlülüklerine oranla daha maliyetli olsa bile, başlangıçta acil nakit finansmanı gerektirmeyen bütçe dışı uygulamalara daha meyilli olabilmektedir (Polackova, 1998: 8).

Üçüncü beklenen fayda ise hükümetlerin KÖi yatırımları ile siyasal müdahale ve baskıların önüne geçme imkanını elde etmesidir. Bilindiği üzere kamu harcamaları siyasetçilerin popülist politikalarından etkilenmekte, gerçekleşen harcamalar zaman zaman iktisadi büyüme ve kalkınma hedeflerinden ayrışmakta ve siyasetçilerin oy maksimizasyonu hedefi doğrultusunda yapılabilmektedir. Özellikle birden fazla yıla yayılı yatırım harcamalarında, belirli bir seviyeye gelmiş yatırımların iptal edilmesi gibi durumlar kaynak israfına yol açmaktadır. KÖi modelinde ise yatırımlar siyasal baskılardan uzak, iktisadi rasyonalite ilkesine uygun ve kısa vadeli kaygılardan ziyade uzun vadeli bir bakış açısı ile gerçekleştirilebilmektedir (Köstekçi, 2017: 316). 
Tokatlıoğlu, M. \& Şen, S. (2019). “Kamu Hizmetlerinin Sunum ve Finansmanında Kamu Özel İşbirliği Modeli: Avrupa Birliği ve Türkiye", International Journal of Public Finance, 4(2), 205-235.

Ancak KÖi modelinin bu potansiyel teorik faydalarına dikkat edildiğinde, çeşitli varsayımlara dayandığı görülmektedir. Bu varsayımların başında ise kamu ve özel kesim arasında risk bölüşümünün adil şekilde gerçekleştiği, rekabetçi bir piyasa sisteminin varlığı ve siyasetin etkisine açık olmadığı yer almaktadır. Oysa KÖi modelinde risk genellikle özel kesim tarafından değil kamu kesimince üstlenilmektedir. Hükümetler, projelerin gerektirdiği acil nakit ihtiyacından kurtulurken -bir sonraki başlıkta değineceğimiz gibi- verdikleri garantiler ile ortaya çıkabilecek riskleri üstlenmiş olmaktadır. Söz konusu garantiler, sözleşme süresine de bağlı olarak hükümeti uzun yıllara yayılı bir taahhüt altına sokmakta, mali açıdan karşılaşılabilecek risk ve belirsizlikleri arttırmaktadır (Aslan \& Duarte, 2014: 6-7). Öte yandan bu projelerin ihale şartlarının kamuoyu ile açık olarak paylaşılmaması, projeyi üstlenen firmaların yasal tekel statüsü kazanması ve böylelikle belirli bir kesime kamu hizmetlerinin sunumu üzerinden kaynak transferinin sağlanması uygulamada karşılaşılan sorunlar arasındadır.

\subsection{KÖi Modelinin Finansmanı}

KÖi, kamu hizmetlerinin üretim ve sunum modeli olduğu kadar, aynı zamanda bir finansman modeli olarak ele alınmaktadır. Çünkü KÖi’nin benimsenmesinde özellikle devletin tümüyle çekilmek istemediği ve devletin katılımı olmaksızın özel sektörün tek başına sunmaktan çekindiği hizmetlerin özel sektörün katılımıyla gerçekleştirilmesi ve böylece devletin temel çıkmazı haline gelen finansman sorununun aşılmak istenmesi etkili olmaktadır (Acartürk \& Keskin, 2012: 27). Kamunun finansman sorununun arkasında ise artan kamu harcamaları ve bütçe açıklarının, ülkelerin yeni altyapı yatırımlarına yönelmesini zorlaştırması, kamu gelirlerinin de aynı hızla yükseltilemeyişi, vergi ödeyenlerin taleplerindeki artışlar vb. faktörler yer almaktadır (Kamu Özel İşbirliği Özel İhtisas Komisyonu, 2018: 2). Böylece KÖi modelleri özellikle kamu kaynaklarının yetersiz kaldığı ülkelerde yapılması planlanan yüksek maliyetli büyük altyapı yatırımlarının yerli ve/veya yabancı özel sektörün katılımı ile bütçe dışı kaynaklarla yapılmasını olanaklı kılmaktadır (Memiş, Karadağ \& Bingöl; 2012: 146). Türkiye'de de KÖi modeli kamu kaynaklarının yetersizliği nedeniyle alternatif bir finansman tekniği olarak görülmektedir (Emek, 2009b: 14).

KÖi modeli, proje finansman ihtiyacının karşılandığı ve özel sektörün de bu ortaklıkla kira geliri elde etme noktasında kârlı olabileceği bir model olarak ele alınmaktadır (Tunç \& Özsaraç, 2015: 3). KÖi finansman modelinin birçok tarafı vardır. Bu taraflar; kamu hizmetlerinin üretimiyle ilgili kamu idaresi, üretimi yapacak özel sektör ortağı, kamu hizmetinin üretiminden fayda sağlayacak bireyler, kamu hizmetlerinin finansmanının içereceği riskleri üstlenen sigorta şirketleri ve kredi kuruluşları olarak ifade edilebilir (Ersöz, 2010: 38). Burada kamu tarafı, KÖi ile kendisinin tek başına klasik tedarik yöntemiyle gerçekleştireceği duruma göre daha fazla katma değer yaratmayı, kamu hizmetinin daha uygun maliyetle ve daha iyi kalitede sunulabilmesini sağlamayı hedeflemektedir. Diğer bir ifadeyle kamu tarafı için yüksek maliyet ve finansman gerektiren hizmetlerin gerçekleştirilmesiyle hizmet arzının 
sağlanması esastır. Kâr maksimizasyonu odaklı hareket eden özel sektör tarafı ise yapılabilir olan ve üstlenilen riskin karşılığında, sözleşme sürecinde, kira gelirinin eşik değer ve üzerinde elde edilmesiyle makul bir getiri sağlama amacındadır. Finansman kuruluşlarının amacı ise yapılabilir ve finanse edilebilir olan KÖi projelerine destek vermektir (Çerçi, 2011: 16; Tunç \& Özsaraç, 2015: 3).

KÖi proje finansmanı modelinde, yatırımı gerçekleştirecek özel sektör firmasının proje finansmanına yatırım tutarının asgari \%20'si oranında bir öz kaynak tutarı ile katılması gerekmektedir (T.C. Kalkınma Bakanlığı, 2014: 7). Oldukça uzun vadeli olan KÖi yatırım projelerinin öz kaynak dışı finansmanına ise ticari bankalar, uluslararası finansal kuruluşlar, çeşitli kurumsal yatırımcılar, fonlar ve stratejik yatırımcılar risk ve vade tercihlerine göre finansman sağlayabilmektedir (Çerçi 2011: 18). KÖi projelerine borç verenler nezdinde önemli olan; proje için verilen kredilerin geri ödenmesinde söz konusu projenin yaratacağı nakit akımlarının dikkate alınması ve proje sahibi şirketin değil, projenin varıklarının kredilerin teminatını oluşturmasıdır (Çerçi, 2011: 17). KÖi modelleri ile gerçekleştirilen projelerde, projenin kendi kendini finanse etmesi esastır. Model uygulanmaya başlamadan önce özel şirketin öz kaynak miktarının belirlenen koşulu sağlaması ve yatırımın devamı için uluslararası kuruluşlardan temin edeceği kredi derecelendirmede belirli bir oranı ya da harf notuna sahip olması gerekmektedir. Ancak piyasa yetersizlikleri ve yapısal kısıtlar gibi nedenlerle projenin kendi kendini finanse etmesi mümkün değilse, devlet tarafından yatırımcı şirketler lehine garanti desteği sağlanabilmektedir (Memiş, Karadağ \& Bingöl; 2012: 146; T.C. Kalkınma Bakanlığı, 2014: 7).

KÖi projelerinin finansmanında kamu garantileri, yatırımın gerçekleşme sürecinde meydana gelen ve gelebilecek risklerin ortadan kaldırılması için ilgili kamu idaresinin verdiği dolaylı desteklerdir. Dolaylı devlet destekleri birtakım koşullara bağlandığı için "koşullu yükümlülükler" olarak adlandırılmaktadır. Koşullu yükümlükler gerçekleştiğinde, yatırımların sürdürülebilirliği için kamu idaresinin üstlenmiş olduğu yükümlülükler garanti niteliğini taşımaktadır (Bülbül \& Atabey, 2010: 63-66). Kamu özel işbirliği ile ilgili kamu garantileri, finansman aşamasında kamu idaresinin özel sektör yatırımcısına borç üstlenim taahhüdünde bulunması şeklinde olduğu gibi, kamu hizmetinin sunumu aşamasında, hizmetin niteliğine göre kamu idaresinin özel sektör yatırımcısından hizmet satın alma garantisi (talep garantisi) vermesi ya da hizmet kapsamında üretilen bina, makine ve ekipmanların özel sektör yatırımcısından kiralanması şeklinde de olabilmektedir (Yusufoğlu, 2017: 165). Bunların dışında kamulaştırma maliyetlerinin üstlenilmesi, enflasyon ve kur riski üstlenimi gibi konularda da kamu garantileri sağlanabilmektedir (Kamu Özel İşbirliği Özel îhtisas Komisyonu, 2018: 43).

Kamu garantilerinin kamu maliyesi açısından önemli yönü, projelerin başarısını etkileyecek kur riski, politik riskler ve benzeri (vb.) oluştuğunda, KÖi projelerinin finansmanı için uluslararası kuruluşlardan alınan kredilerin geri ödenememesi sonucu, devletlerin garantisi altındaki bu kredilerin kamu borcuna dönüşme ihtimalinin 
artmasıdır. Ayrıca talep veya kullanım garantisi gibi garantilerin uzun döneme yayılan kamusal taahhütler (25-30 yıl gibi) olduğu göz önüne alındığında uzun dönemde hükümetlerin karşılaşacağı belirsizlikler artmaktadır. Nitekim koşullu yükümlülüklerin en karakteristik özelliği de söz konusu bu belirsizliklerdir (Hemming, 2006: 9). Bu bağlamda IMF, KÖi projelerinin uygulanmasıyla ortaya çıkan ekonomik risklere karşı alınabilecek önlemler kapsamında verilen kamu garantilerinin kendisinin de ekonomik riske sebep olacağını belirtmektedir. Kamu garanti yönetimi ve sürdürülebilir borç yönetimi bağlamında ülkelerin alabileceği bazı önlemlerin olduğu ifade edilmektedir (Hemming, 2006: 9-10).

Buna göre KÖi projelerinin gerçek ekonomik koşullara ve ihtiyaçlara göre belirlenmesi, verilen garantiler ile ekonomik risklerin artması halinde bu sürecin yönetiminin sağlanması, ülkelerin gerçekleştirdiği yatırımlar için ulusal ve uluslararası arenadan temin edilen finansal yatırım kredilerinin yani borçlanmanın sürdürülebilir bir seviyede gerçekleştirilmesi üzerinde durmaktadır. KÖi projelerini hayata geçiren gelişmiş ve gelişmekte olan ülkelerin kamu borcunu çevirme oranı ülke aleyhine yükseldiğinde kur riski arttığı için, projelerin gelecekteki maliyetinin kapsamlı bildiriminin yapılmasının gerekli olduğunu vurgulamaktadır. Özellikle 2008 Krizi ve ardından yaşanan Avrupa Borç Krizi sonrasında da IMF'nin kamu borcu ile ilgili bu uyarılarını devam ettirdiği görülmektedir.

\section{Avrupa Birliği Ve Türkiye'de Kamu Özel İşbirliği Uygulamaları}

Türkiye'de KÖi uygulamaları dünyadaki gelişmelere paralel biçimde 1990'larda başlamıştır. Dolayısıyla Türkiye'yi değerlendirebilmek için diğer ülkelerdeki uygulamalara da bakmak gerekir. Türkiye'nin Avrupa Birliği'ne aday bir ülke olması Avrupa Birliği'ndeki uygulamaları anlamayı ve değerlendirmeyi gerekli kılmaktadır.

\subsection{Avrupa Birliği'nde Kamu Özel İşbirliği Uygulamaları}

KÖi modelinin Avrupa Birliği ülkelerinde gelişiminin uygun bir zemin bulmasını iki temel gerekçe üzerinden açıklamak mümkündür. Birincisi, dünyada ekonomik liberalleşme yönünde adımların atıldığı 1980'li yıllarda, Avrupa'da da ekonomik entegrasyon sürecinin gerektirdiği liberalleşme adımlarının atılması kamu hizmet alanlarına özel sektörün girmesini teşvik etmiştir. Diğer bir ifadeyle Avrupa Birliği'nin, Tek Pazar hedefine ulaşmak için mal, hizmet, sermaye ve emeğin serbest dolaşımını sağlamak üzere aldığı önlemler, üye ülkelerin, tekel niteliğindeki kamu hizmet alanlarını serbestleştirmesi (EPSU, 2004), yani kamu hizmet alanlarını özel kesime açması ve kamu iktisadi teşebbüslerini özelleştirmesine önemli bir gerekçe olmuştur. İkincisi ise, 1990'। yılların başında ekonomik ve parasal birlik hedefini gerçekleştirmek üzere yürürlüğe giren Maastricht Antlaşması'nın, Tek Avrupa Parası Euro'nun istikrarı'nı sağlamak üzere üye ülkelerin maliye politikalarını baskı altına alan bütçe açığı (\%3) ve kamu borcu (\%60) ile 
ilgili "yakınlaşma kriterleri"dir (bkz: Tokatlıoğlu, 2004: 63). İşte bu kriterleri yerine getirmekle yükümlü olan üye ülkelerin, devlet bütçesinden kamu hizmetlerine ayrılan payı azaltma zorunluluğu ile karşı karşıya olması, artan kamu alt yapı ihtiyaçlarının giderilmesinde özel sektöre başvurması ve kamu özel işbirliği projelerine yönelmesinde etkili olmuştur (Cour des Comptes Européenne, 2018: 17; Van Thiel, 2007: 91).

Avrupa Birliği'nin KÖi’ye yaklaşımını, "bir altyapı hizmetinin inşasını, bakım onarımını, finansmanını, yönetimini ve/veya bir kamu hizmetinin sunumunu sürdürmek amacıyla kamu idareleri ve özel teşebbüsler arasında oluşturulan işbirliği politikaları" olarak ifade etmek mümkündür (Emek, 2009a: 19). Komisyon'un, 2003 yılında, kamu özel işbirliği projeleri için $A B$ fonlarından yararlanmak isteyen üye ve aday ülkelere yönelik yayınladığı rehberde, kamu özel işbirliğinde özel sektörün dört temel rolünün olduğu vurgulanmaktadır. Bunlar; ek sermaye temin etmek, yönetim becerilerini ortaya koymak, tüketiciye ve daha geniş ölçekte kamuya katma değer sağlamak, ihtiyaçların daha iyi tanımlanmasını ve kaynakların optimal kullanımını sağlamak olarak ifade edilmiştir (European Commission, 2003: 7). Politika metinlerinde kamu özel işbirliği (public private partnership) terimi kullanılsa da Topluluk düzenlemelerinde hukuki olarak KÖi yerine "imtiyaz" kavramı kullanılmaktadır. 2004 yılında AB Komisyonu'nun kabul ettiği "Kamu Özel İşbirlikleri ve Topluluk Hukukunda Kamu ìhaleleri İle İmtiyazlara İlişkin Yeşil Kitap" (bkz: TC. Maliye Bakanlığı, 2010), üye ülkelerdeki KÖi uygulamalarının "imtiyaz sözleşmeleri" ve "kurumsal kamu özel işbirlikleri" şeklinde iki ayrı model üzerinde yoğunlaştığını belirtmektedir (Emek, 2009a: 19-20; TC. Maliye Bakanlığı, 2010: 7-11). İmtiyaz sözleşmelerine dayalı KÖi projeleri, projenin tasarımı, finansmanı, yapımı ve işletilmesinde sözleşmedeki ilişkiye dayalı bir işbirliği söz konusudur. Bu modelde yatırım bedelinin ödenmesi, kullanıcılardan yararlanma bedeli ve devletin sağlayacağı sübvansiyonlarla yüklenici özel sektör yatırımcısına ödeme şeklinde olmaktadır. Kurumsal, dolayısıyla tüzel kişiliğe sahip KÖi projelerinde ise, özel sektör yatırımcısı kamu hizmetinin alt yapısının inşası ve işletilmesi amacıyla davet edilmektedir. Bu yöntem "Özel Finansman Girişimi” (Private Finance Initiative) olarak daha çok okul, hastane, ulaşım, cezaevi inşası projelerinde görülmektedir. Özel sektöre ödenecek bedel, kullanıcılar üzerinden değil, kamu idaresinin projeye yıllık belirli bir bedel ödemesi şeklinde uygulanmaktadır (Emek, 2009a: 12).

AB ülkelerindeki KÖi uygulamaları EPEC (Avrupa Kamu Özel Ortaklığı Danışma Merkezi) verileri üzerinden takip edilebilmektedir. EPEC, $A B^{\prime}$ ye üye ülkelerde alt yapı projelerinin finansmanında önemli bir rol oynayan Avrupa Yatırım Bankası bünyesinde 2008 yılında oluşturulmuş bir kuruluştur. Banka'dan fon sağlayacak ülkeler ile yatırımı gerçekleştirecek firmalara proje planlama, ihale, yatırım ve işletme aşamalarında destek vermektedir (http://www.eib.org/epec). EPEC verilerine dayanılarak hazırlanan aşağıdaki ilk üç grafik, 1990-2018 döneminde Avrupa Birliği ülkelerinde hayata geçirilen KÖi projelerinin yatırım değeri ve proje sayıları bakımından gelişimini, yatırım değerlerinin ve proje sayılarının sektörel dağılımlarını ortaya koymaktadır. 
Aşağıdaki Grafik 1, AB ülkelerinde KÖi projelerinin yatırım değeri ve proje sayıları bakımından gelişimini göstermektedir. Buna göre, 1990-1994 yıllarında her yıl yatırım değerleri 1 milyar Euro'nun altında olan 1'er projenin hayata geçirildiği görülmektedir. Maastricht Antlaşması'nın getirdiği bütçe kısıtlarının etkisini göstermeye başladığı 1990'lı yılların ortalarından itibaren kamu yatırımlarında kamu özel işbirliği projeleri ile gerçekleştirilen proje sayılarının ve yatırım büyüklüklerinin arttığı görülmektedir. Nitekim 1995 yılında proje sayısı 10, yatırım büyüklüğü 2.88 milyar Euro iken, bu sayılar sırasıyla 1998 yılında 59 ve 19.69 milyar Euro'ya yükselmiştir. İlerleyen yıllarda artış eğilimi Küresel ekonomik krize kadar devam etmiştir. 2007 yılında toplam yatırım tutarı 26.79 milyar Euro olan 129 proje hayata geçirilmiştir. 2008 yılından sonra ise Küresel kriz koşullarının getirdiği kaybolan güven ortamı, daralan kredi imkânları ve hükümetlerin karşılaştıkları mali açıdan sürdürülebilirlik sorunu KÖi pazarının daralmasını beraberinde getirmiştir. Bu daralma 2010-2012 yıllarındaki Avrupa Borç Krizi sürecinde de sürmüş, yatırım büyüklüğü 2010 yılında 18.33 milyar Euro ve proje sayısı 107 iken, 2012 yılında bu sayılar 12.08 milyar Euro ve 62 olarak gerçekleşmiştir. 2013 yılında tekrar bir artış söz konusu söz konusu olsa da (yatırım büyüklüğü 20.99 milyar Euro ve proje sayısı 82) 2014 yılından itibaren hem yatırım büyüklüğü hem de proje sayılarında ciddi bir düşüş olmuştur. 2018 yılı itibariyle Avrupa KÖi pazarının toplam yatırım değeri 14.61 milyar Euro ve proje sayıları 39 'dur.

\section{Grafik 1: 1990-2018 Yılları İtibariyle Avrupa Birliği Ülkelerinde Köi Projelerinin Yatırım Değeri ve Proje Sayıları Bakımından Gelişimi}

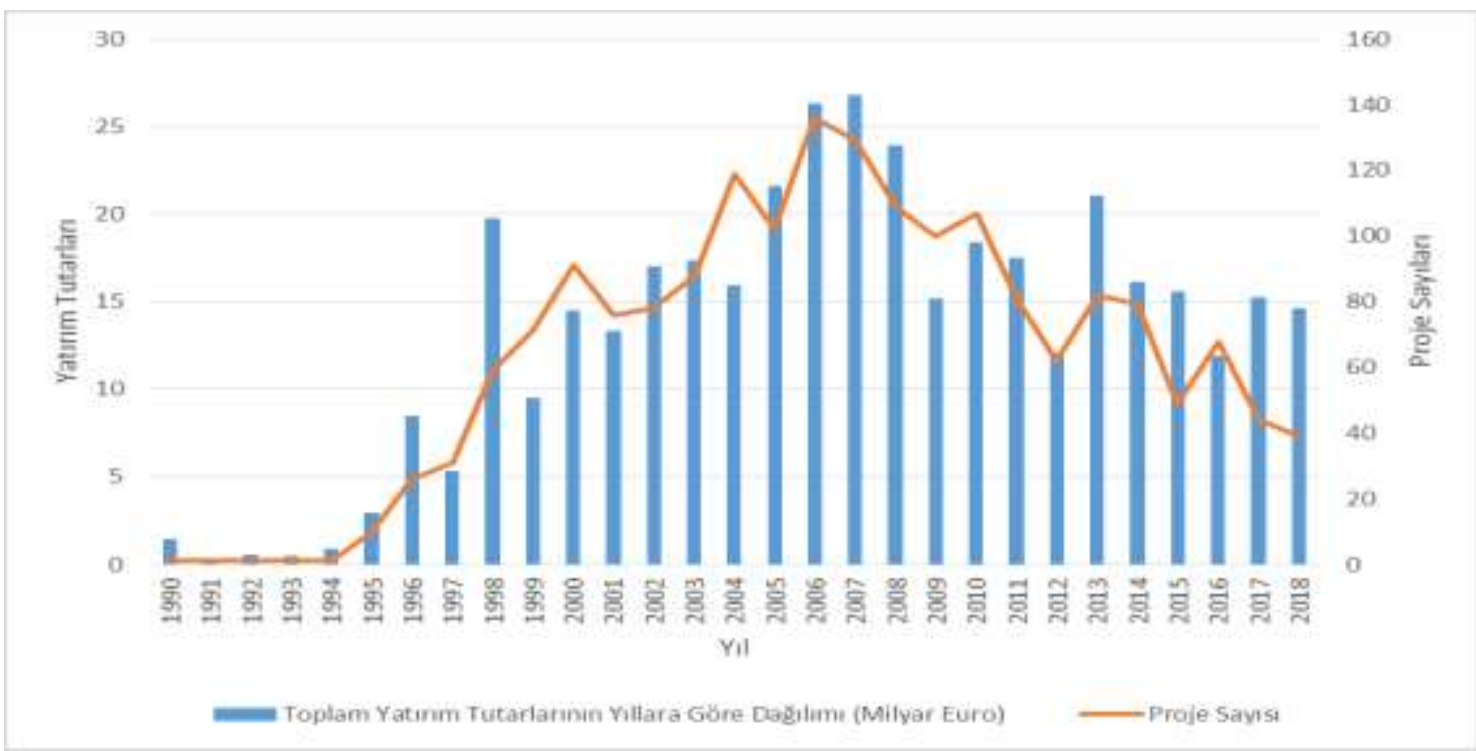

Kaynak: EPEC, https://data.eib.org/epec (08.07.2019).

Aşağıdaki Grafik 2, Avrupa Birliği ülkelerinde yatırım büyüklüğü bakımından sektörlerin toplam içindeki payını göstermektedir. Buna göre toplam yatırım 
büyüklüğünden en büyük pay \%55.3 ile ulaşım hizmetleri ve \%13.2 ile sağlık hizmetleri ile ilgili KÖi projelerine gitmektedir. Diğer kamu hizmet alanlarındaki KÖi projelerinin payı ise eğitim hizmetlerinde \%9.3; çevre hizmetlerinde \%6.3; güvenlik ve savunma hizmetlerinde \%4.7; kamu düzeni ve güvenliği hizmetlerinde \%3.3; konut ve toplumsal hizmetlerde \%1.9, telekomünikasyon hizmetlerinde \%1.9; genel kamu hizmetlerinde \%1.9; eğlence ve kültür hizmetlerinde \%1.7 ve araştırma-geliştirme hizmetlerinde $\% 0.0042$ olarak gerçekleşmiştir.

\section{Grafik 2: 1990-2018 Yılları İtibariyle Avrupa Birliği Ülkelerinde KÖi Projelerinin Toplam Yatırım Değerinin Sektörel Dağılımı (Yüzde Olarak)}

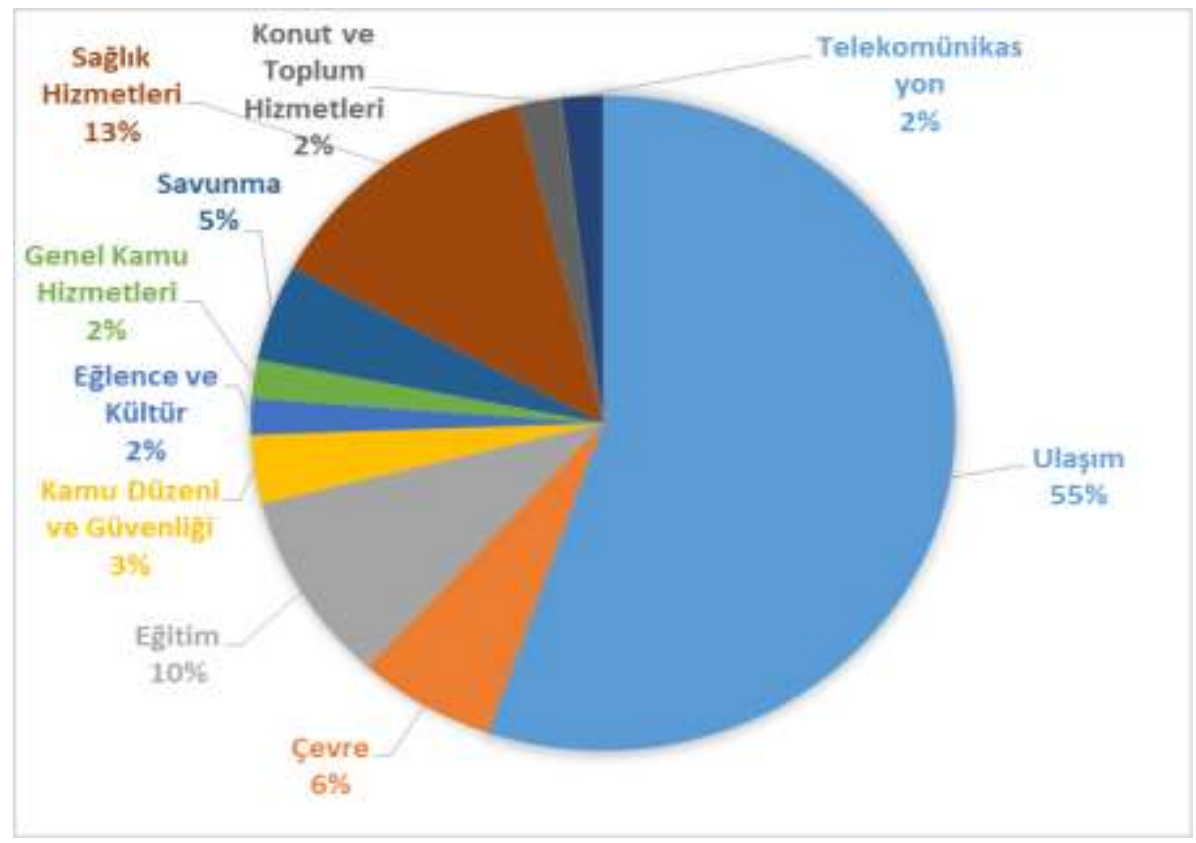

Kaynak: EPEC, https://data.eib.org/epec (08.07.2019).

1990-2018 yılları itibariyle, Avrupa Birliği ülkelerinde KÖi modeli ile toplam 383.173 milyar Euro yatırım değeri olan toplam 1841 proje gerçekleştirildiği görülmektedir. Aşağıdaki Grafik 3, Avrupa Birliği ülkelerinde gerçekleştirilen KÖi proje sayılarının toplam proje sayısı içindeki payını göstermektedir. Toplamdan en büyük payları eğitim, sağlık ve ulaşım hizmetlerinin aldığı söylenebilir. Buna göre çeşitli sektörlerin kamu hizmetleri ile ilgili toplam içindeki dağılımı şu şekildedir: eğitim \%24 (443 proje), sağıık \%21 (393 proje), ulaşım \%21 (391 proje); kamu düzeni ve güvenliği \%8 (147 proje); kamu düzeni ve güvenliği \%8 (147 proje); çevre \%8 (143 proje); konut ve toplumsal hizmetler \%5 (83 proje); eğlence ve kültür \%4 (80 proje); genel kamu hizmetleri \%4 (76 proje); savunma \%3 (56 proje) telekomünikasyon \%2 (27 proje); araştırma-geliştirme \%0.01 (2 proje)'dir. 
Tokatlıoğlu, M. \& Şen, S. (2019). “Kamu Hizmetlerinin Sunum ve Finansmanında Kamu Özel İşbirliği Modeli: Avrupa Birliği ve Türkiye", International Journal of Public Finance, 4(2), 205-235.

\section{Grafik 3: 1990-2018 Yılları İtibariyle Avrupa Birliği Ülkelerinde Toplam KÖi Proje Sayılarının Sektörel Dağılımı (Yüzde olarak)}

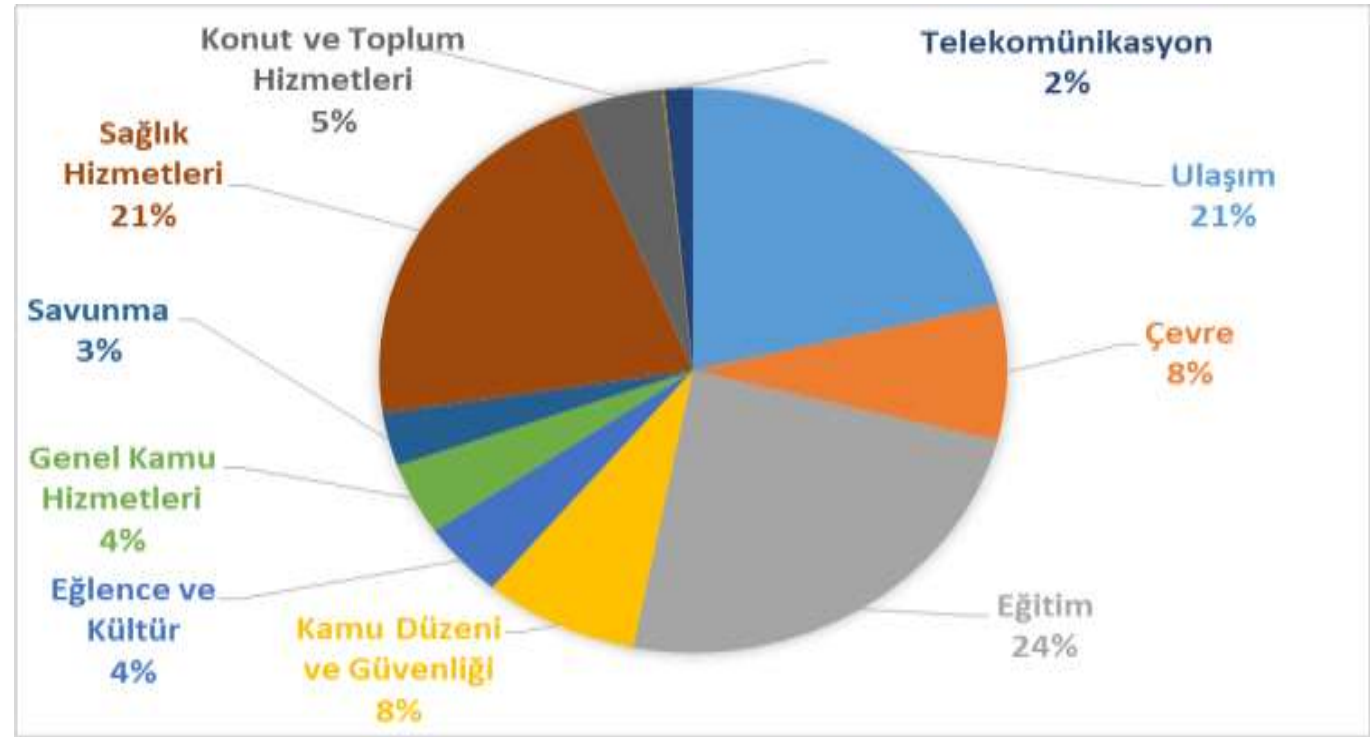

Kaynak: EPEC, https://data.eib.org/epec (08.07.2019).

Avrupa Birliği'nde son yıllardaki KÖi uygulamaları ülke bazında yatırım tutarı bakımından ele alındığında İngiltere, Fransa, Hollanda gibi ülkeler başı çekmektedir. Grafik 4, 2014-2018 yılları itibariyle bazı Avrupa Birliği ülkelerinde gerçekleşen KÖi projelerinin yatırım tutarlarını göstermektedir (Türkiye bir sonraki başlıkta ele alınsa da, durumun ilginç olması nedeniyle, Grafik 4'te Birlik üyesi olmayan Türkiye'ye ilişkin tutarlar da yer almaktadır).

\section{Grafik 4: 2014-2018 Yılları İtibariyle Bazı Avrupa Birliği Ülkelerinde Gerçekleşen Toplam Köi Yatırım Tutarları}

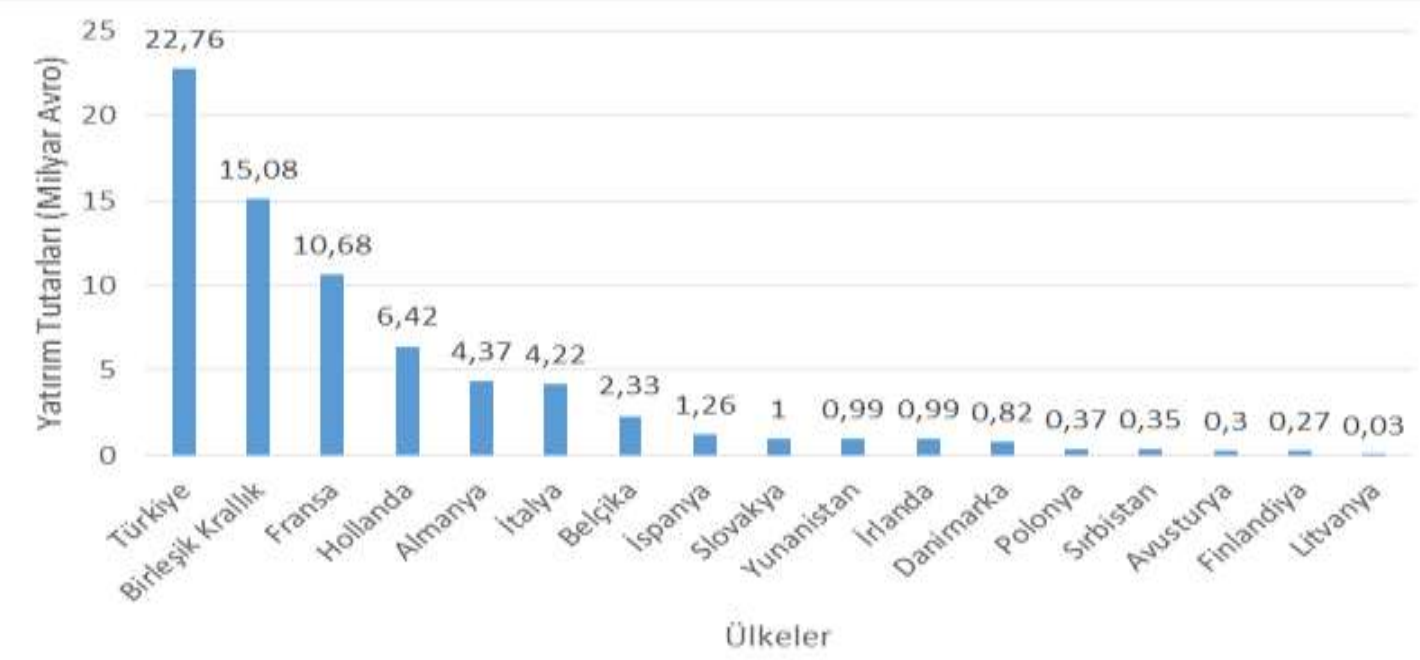

Kaynak: T.C. Strateji ve Bütçe Başkanlığı, 2019: 11 
Buna göre Türkiye, söz konusu yıllar arasında gerçekleştirdiği 22.76 milyar Avro tutarındaki KÖi yatırımları ile Avrupa'da en büyük KÖi pazarına sahip ülke durumundadır. Nitekim Avrupa'da, 2018 yılı itibariyle finansal kapanışı gerçekleştirilen, yatırım tutarları itibariyle en büyük sekiz projeden üç tanesi Türkiye'dedir. Bu üç projeden Çanakkale Köprüsü (3.1 milyar Avro) ve Ankara-Niğde Otoyolu (1.2 milyar Avro) projeleri sırasıyla Avrupa'nın en büyük iki KÖi yatırımıdır. Bilkent Laboratuvarı (711 milyon Avro) ise bu alanda en büyük yedinci sıradaki projedir (T.C. Strateji ve Bütçe Başkanlığı, 2019: 11-12).

\subsection{Türkiye'de Kamu Özel İşbirliği Uygulamaları}

Devletin ekonomideki rolünün sınırlandırılması görüşünün dünyada kamu hizmetlerinin sunum ve finansman biçiminde yarattığı dönüşüm Türkiye'yi de etkilemiş ve bu doğrultuda 24 Ocak 1980 kararları ile başlayıp 1990'larda sürdürülen liberalleşme ve özelleştirme politikaları Türkiye'de kamu özel işbirliği uygulamalarının zeminini hazırlamıştır. 1970'li yılların ortalarından itibaren ekonomide artan iç ve dış kaynaklı istikrarsızlıklara çözüm bulmak amacıyla yürürlüğe konulan 24 Ocak 1980 ekonomik istikrar ve yapısal uyum programı, sadece ekonomik istikrarsılıkları gidermek için değil, aynı zamanda yeni bir ekonomik modeli hayata geçirmek için alınan önlemlerdir. Bu önlemlerin amacı devletin ekonomide yatırımcı ve üretici olarak yer aldığı ithal ikameci ekonomi modelinden dışa açık ekonomi modeline geçilmesi, bunun için devletin ekonomideki rolünün azaltılması, piyasa ekonomisine işlerlik kazandırımasını içermektedir. Bu doğrultuda dış ticaretin serbestleştirilmesi, ihracatın teşvik edilmesi, yabancı sermayenin ülkeye girişinin teşviki ve kiT’lerin özelleştirilmesi politikaları uygulanmıştır. 1990'lı yıllarda bu politikalar kısa vadeli sermaye hareketlerinin serbestleştirilmesi ile desteklenerek sürdürülmüştür. Ancak özelleştirme politikalarında karşılaşılan hukuki sorunlar uygulamada tıkanıklıklara yol açmıştır. Öte yandan bu liberalleşmeyi destekleyici yani özel sermaye üzerindeki vergi yükünü azaltıcı vergi politikası uygulanmasına rağmen kamu harcamalarının azaltılamamasının yarattığı kamu finansman sorunları önce 1994 Krizinin, ardından 2001 Krizinin yaşanmasına yol açmıştır.

2001 Krizi sonrasında mali disiplini sağlamaya dönük yapısal önlemler ve özelleştirme uygulamalarına hız verilmesiyle kamudaki finansman sorunları büyük ölçüde çözülmüştür. İlerleyen yıllarda mali disiplini koruyacak maliye politikaları benimsenmiştir. Yatırım ortamın iyileştirilmesi ve özel girişimciliğin teşvik edilmesine yönelik yasal ve kurumsal önlemler alınmıştır. Diğer taraftan kalkınmak için gerekli altyapı yatırım ihtiyacının artması ve kamuda mali disiplini sürdürme amacı kamu özel işbirliği projelerine yönelmeyi ve bunun için yasal alt yapının oluşturulmasını beraberinde getirmiştir. Aslında Türkiye için kamu hizmetlerinin özel sektöre gördürülmesi yeni bir durum değildir. Bugün hala yürürlükte olan 1910 tarihli Menafii Umumiyeye Müteallik İmtiyazat Hakkında Kanun kamu hizmetinin imtiyaz yöntemi ile gördürülmesine imkan vermektedir. 1984 yılından beri yapılan çeşitli yasal 
düzenlemeler ise otoyol, köprü, tünel, havalimanı, sağlık ve enerji gibi birçok sektörde yap-işlet-devret, yap-işlet, yap-kirala, işletme hakkı devri gibi daha karmaşık nitelikteki KÖi modellerinin uygulanmasını sağlamaktadır. Bugün bu modellere yap-kirala-devret modeli de eklenmiştir. Konu ile ilgili geniş bir mevzuat oluşmuş görünmektedir (ayrıntılı bilgi için bkz: T.C. Kalkınma Bakanlığı, 2015).

KÖi uygulamalarının değerlendirilmesine gelince, bu değerlendirmeyi Avrupa Birliği başlığında olduğu gibi birtakım veriler üzerinden ortaya koymak mümkündür. Strateji ve Bütçe Başkanlığı'nın verilerinden yararlanarak hazırlanan aşağıdaki grafikler, Türkiye'de 1986-2018 yılları itibariyle KÖi projelerinin toplam yatırım değeri ve proje sayılarını, bunların sektörel dağılımlarını göstermektedir. Buna göre KÖi projelerinin ilki 1986 yılında olmak üzere, o tarihten bugüne, 210 adedi işletmede, 32 adedi ise finansal kapanış ya da yapım aşamasında olmak üzere, toplam yatırım değeri 2019 yılı fiyatlarıyla 68.8 milyar ABD Doları olan 243 proje uygulamaya konmuştur. Gerçekleştirilen 243 projeden 109 adedi yap-işlet-devret ve işletme hakkı devri modelleri ile gerçekleştirilirken, 20 adedi yap-kirala-devret ve 5 adedi de yap-işlet modeli kullanılarak gerçekleştirilmiştir (T.C. Strateji ve Bütçe Başkanlığı, 2019: 22). Proje sayılarının ve yatırım değerlerinin yıllara göre dağııımı aşağıdaki Grafik 4'te gösterilmektedir.

\section{Grafik 5 1986-2018 Yılları İtibariyle Türkiye'de Köi Projelerinin Yatırım Değeri (ABD Doları) ve Proje Sayıları Bakımından Gelişimi}

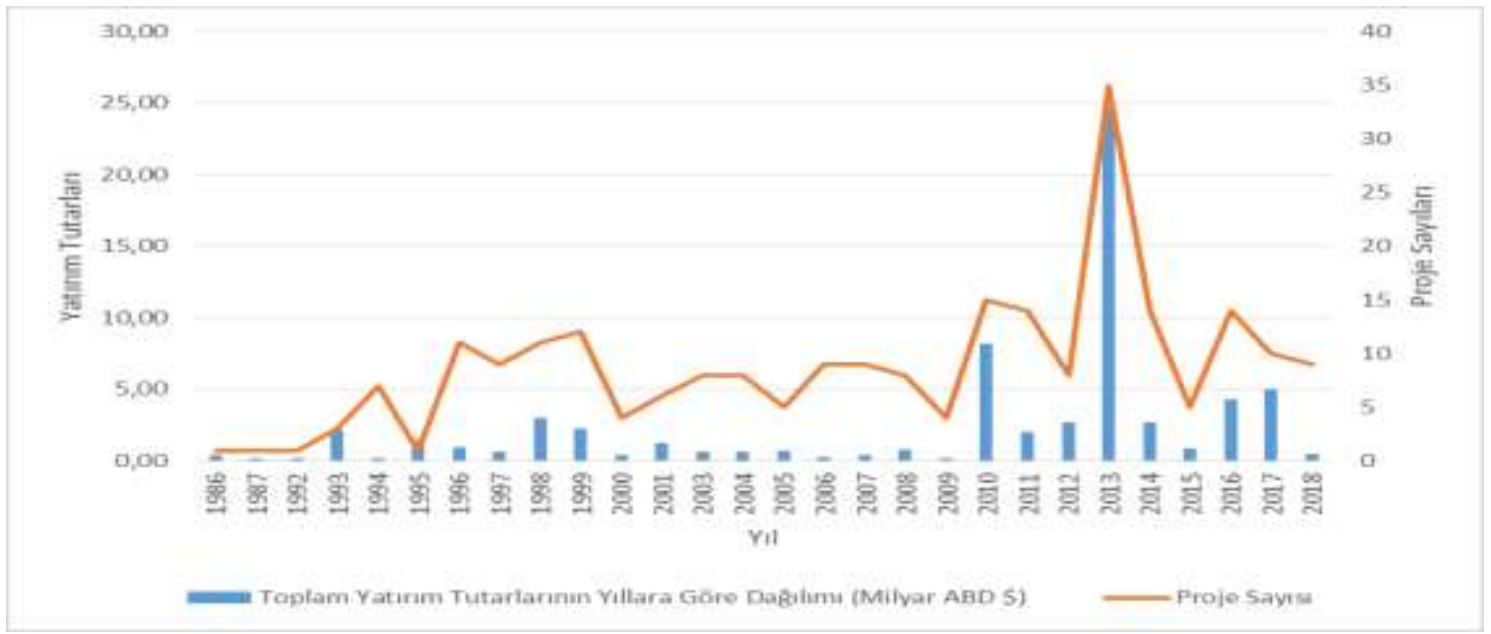

Kaynak: T.C. Strateji ve Bütçe Başkanlığı

Yukarıdaki Grafik 5 incelendiğinde 2008 yılından başlayarak KÖi yatırımlarına olan ilginin geçmişe oranla arttığı görülmektedir. Projelerin sayısındaki artışa paralel şekilde yatırımların tutarı da gözle görülür biçimde artış sergilemiştir. KÖi yatırımlarındaki artışın 2008 yılından itibaren gerçekleşmesi, Küresel krizin etkisiyle ülkelerin yaşadığı mali sıkıntıların bir benzerinin Türkiye'de de yaşanması noktasında değerlendirilebilir. Ayrıca KÖi projeleri ile ilgili yasal mevzuattaki eksikliklerin bu tarihten itibaren tamamlanması, söz konusu yatırımların artmasındaki ana etkenler arasında sayılabilir (Kamu Özel İşbirliği Özel İhtisas Komisyonu, 2018: 45). 


\section{Grafik 6 1986-2018 Yılları İtibariyle Türkiye'de KÖi Proje Sayılarının Sektörel Dağılımı (Yüzde olarak)}

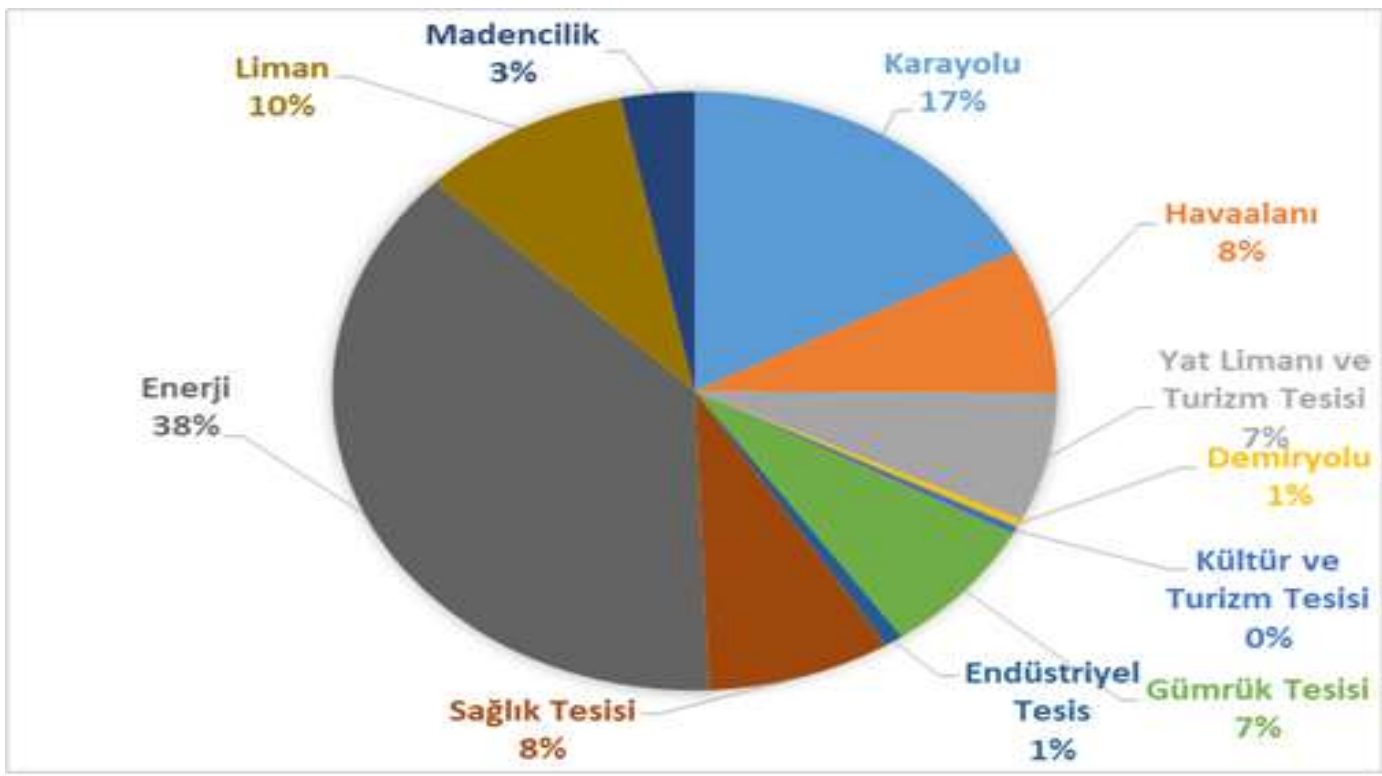

Kaynak: T.C. Strateji ve Bütçe Başkanlığı

Yukarıdaki Grafik 6 ise, 1986'dan 2018'e kadar gerçekleştirilen 243 KÖi projesinin hangi sektörlerde yoğunlaştığını göstermektedir. Buna göre, söz konusu yatırımlardan en büyük payı \%38 ile enerji sektörü almıştır. Enerji sektörünü sırasıyla karayolu, havaalanı ve sağlık yatırımları izlemiştir. Bu dört sektörde gerçekleşen proje sayısı toplam proje sayısının \%71'ini oluşturmaktadır.

\section{Grafik 7 Köi Projelerinin Yatırım Tutarlarının Sektörel Dağııımı (Yüzde olarak)}

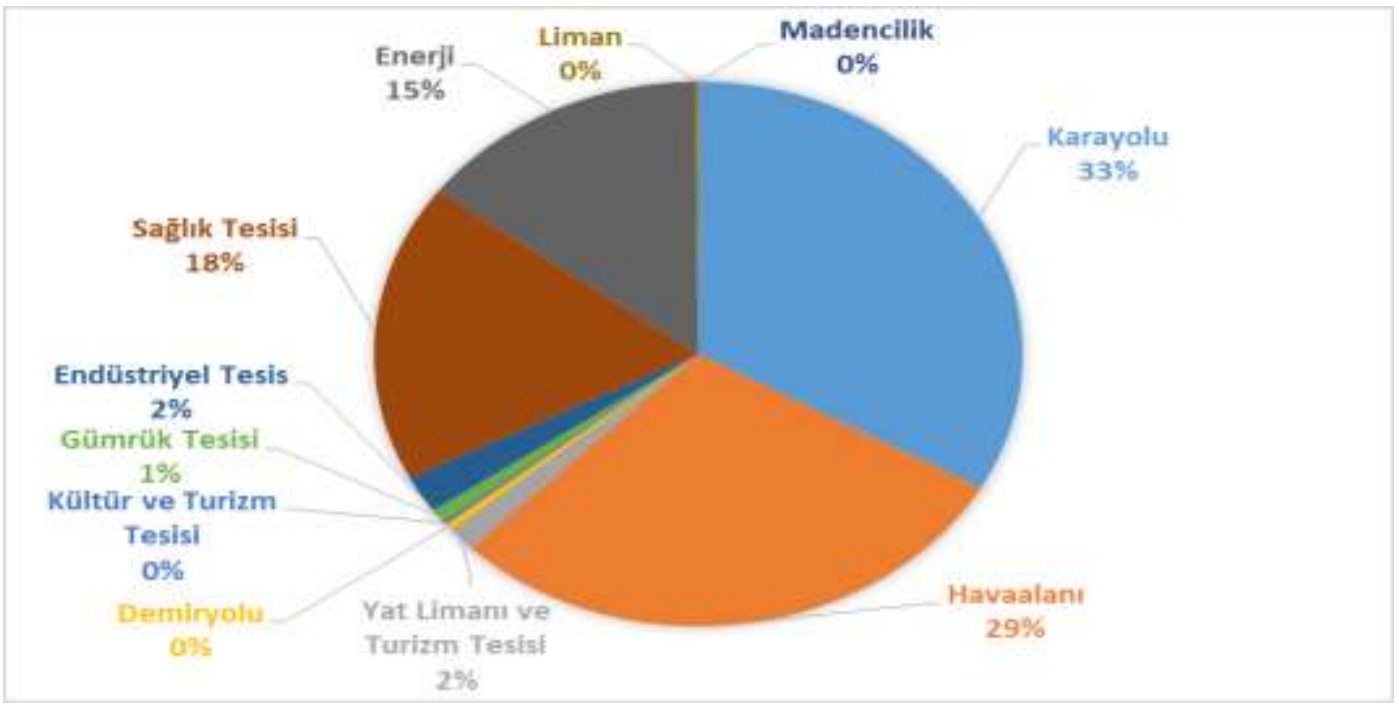

Kaynak: T.C. Strateji ve Bütçe Başkanlığı 
Buna karşılık Grafik 7'da KÖi projeleri toplam yatırım tutarları bakımından incelendiğinde ise en büyük payı alan sektörlerin sırasıyla karayolu, havaalanı ve sağlık tesisi yatırımları olduğu görülmektedir (Avrasya Tüneli, Osmangazi Köprüsü, İstanbul Havaalanı, Şehir Hastaneleri vb.). Bu üç sektörde gerçekleşen yatırımlar, 1986 yılından 2018 yılına kadar gerçekleşen toplam KÖi yatırımlarının \%80'ini oluşturmaktadır. Enerji sektörü ise toplam KÖi yatırımlarından yalnızca \%15 düzeyinde bir pay alabilmiştir.

\section{Sonuç}

Devletin ekonomideki rolünün sınırlandırılması anlayışının kamu hizmetlerinin sunum ve finansmanındaki yansıması kamu özel işbirliği projelerinin ortaya çıkması ile mümkün olabilmiştir. KÖi projelerinin, artan altyapı yatırım ihtiyacının gerektirdiği mali yükü kısa vadede hükümetlerin üzerinden alması ise yöntemin hükümetler tarafından kolaylıkla benimsenmesine yol açmıştır. Esasında söz konusu projelerin kökleri 17. yüzyıla kadar uzanmaktadır. Ancak günümüzdeki uygulamaları ile kıyaslandığında son derece basit ve sınırlı kalan bu uygulamaların modern versiyonları eğitimden sağlığa, ulaşımdan enerjiye çok daha geniş bir kamu hizmet yelpazesini kapsamakta ve daha karmaşık bir görünüm arz etmektedir.

KÖi projeleri gerek kamu hizmetinden faydalananlar açısından, gerekse de kamu maliyesi açısından bazı sakıncalar ortaya çıkarmaktadır. Sunulan kamu hizmetinden faydalananlar açısından KÖi projeleri, hizmetin vergi ile finanse edilerek devlet eliyle sunulduğu geleneksel yönteme göre daha maliyetli olmasına yol açmaktadır. Çünkü devlet, kamu hizmetlerini sunarken ilkesel olarak kâr amacı gütmez. Ancak KÖi projesi altında gerçekleşen kamu hizmetinin sunumunda, özel kesimin temel motivasyonu kâr olmaktadır. Temeli devlet ile özel kesim arasındaki risk ve yönetim sorumluluğunun bölüşümüne dayanan KÖi projelerinin kamu maliyesi açısından yarattığı sakıncalar ise risk paylaşımının adil gerçekleşmeyerek, devlet aleyhine sonuçlar ortaya çıkarmasından ileri gelmektedir. Özel kesimin KÖi projelerine olan ilgisini arttırmak adına verilen kamu garantileri hükümetlerin koşullu yükümlülüklerini arttırmaktadır. Bu durum, kamu harcamalarında ve kamu borç stokunda beklenmedik artışlar yaratırken, mali disiplinin bozulmasına yol açabilmektedir. Özellikle iyimser tahminler altında verilen talep garantileri ve/veya kullanım garantileri gibi garantiler hükümetleri uzun yıllara yayılı taahhütler altına sokarken, gelecek hükümetlerin de hareket alanını daraltmakta, bütçe kısıtını arttırmaktadır. Örneğin eğitim, sağlık gibi kalkınma açısından verimli alanlara ayrılabilecek kaynaklar, yapılan hatalı tahminler neticesinde az sayıdaki özel şirkete transfer edilirken; gelecek nesillerin refah düzeyi de olumsuz etkilenebilmektedir. Yatırımların devlete maliyeti ise gerçek maliyetinin üzerine çıkabilmektedir. KÖi yatırımlarının kamu maliyesi açısından doğurduğu sakıncalardan bir diğeri ise mali şeffaflık meselesidir. Teorik olarak tahakkuk esaslı muhasebe sistemi altında harcamanın gerçekleşme riski sıfırdan büyük olduğunda bütçeden ödenek ayrılmaktadır. Ancak bu riskin doğru hesaplanamaması ya da bütçelemede tahakkuk esaslı muhasebe sisteminin benimsenmeyişi yapılan 
transferlerin bütçe hesaplarında tam olarak görülememesine yol açabilmektedir. Diğer taraftan, özellikle gelişmekte olan ülkelerde kÖi projelerinde gerçekleştirilen sözleşmelerin ve verilen kamu grantilerinin kamuoyu ile paylaşılmaması söz konusu olabilmektedir. Ortaya çıkan bu gibi durumların mali şeffaflık kriterleri ile örtüşmediği söylenebilir.

KÖi projeleri bugün Dünya genelinde artış göstermiştir. Ancak çalışmada $A B$ ve Türkiye incelenmiştir. Dünyadaki gelişmelere paralel olarak $A B$ ve Türkiye'de de KÖi yatırımları artmıştır. AB'de 1990'lı yılların ortasından başlarayarak devam eden artış trendi Küresel Kriz ve Avrupa Borç krizi ile kaybolurken, Türkiye'de 2000'li yılların ikinci yarısında başlayan artış trendi Küresel kriz sonrası daha da hız kazanmıştır. Çalışmada, $A B$ ve Türkiye açısından proje sayılarında ve yatırım tutarlarında gerçekleşen bu dönemsel farklılık, iç dinamikler ve kriz olgusu ile izah edilmeye çalışılmıştır. Konunun geniş olduğu ve sınırlandırılması gerektiği inancıyla Türkiye açısından analize dahil edilmeyen ancak en azından sonuç kısmında vurgulanmasının faydalı olduğunu düşündüğümüz iki husus vardır. Birincisi KÖi projelerinin getirdiği koşullu yükümlülüklerle ilgilidir. Türkiye'de KÖi yatırımlarında, sağlıktan ulaşıma kamu garantilerine yaygın şekilde başvurulmuştur. Bu durum kamu maliyesinin ileride karşılaşabileceği risk ve belirsizlikleri arttırmaktadır. Dolayısıyla Türkiye'de kamu özel işbirlikleri, koşullu yükümlülükler açısından da incelenmeye muhtaçtır. İkincisi ise konunun hukuki boyutudur. Türkiye'de bu konudaki yasal mevzuat oldukça dağınık haldedir. Dolayısıyla Türkiye'de kamu özel işbirliklerinin hukuki altyapı ve koşullu yükümlülükler açısından ayrı çalışmalarla ele alınmasında fayda vardır.

\section{Kaynakça}

Acar, I.A. (2012). "Kamu-Özel Sektör Ortaklıkları Kamu Hizmeti Sunumunu Etkinleştirebilir mi?”, Vergi Sistemlerinin Yeniden Yapılandırılması Gereği ve Alternatif Finansman Arayışları, 27. Türkiye Maliye Sempozyumu, İstanbul Üniversitesi İktisat Fakültesi Maliye Bölümü, 20-24 Mayıs 2012, Antalya.

Acartürk, E. \& Keskin, S. (2012). "Türkiye'de Sağlık Sektöründe Kamu Özel Ortaklığı Modeli", Süleyman Demirel Üniversitesi iktisadi ve Idari Bilimler Fakültesi Dergisi, 17(3), 25-51.

Akdemir, T. \& Karakurt, B. (2010), "Sağlık Hizmetlerinde Devletin Değişen Rolü ve Özel Sağlık Kurumlarını Düzenleyici Görevleri”, Devletin Değişen Rolü Bağlamında Türkiye'de Kamu Harcamalarının Sektörel Analizi, (Ed.) Gümüş, E., Çelikay, F. \& Öz, G., 24. Türkiye Maliye Sempozyumu Tebliğler Kitabı, Eskişehir Osmangazi Üniversitesi İktisadi ve İdari Bilimler Fakültesi Maliye Bölümü, 19-23 Mayıs 2009-Antalya, Eskişehir, 221-260.

Akdoğan, A. (1993). Kamu Maliyesi, 4. Baskı, Gazi Büro Kitabevi, Ankara. 
Akıllı, H. (2013). "Kamu Hizmeti İmtiyazından Yap İşlet Devret Yöntemine: Yasal Serüven", Sayıştay Dergisi, 19, 91-114.

Aktan, C. C. (1987). Kamu Iktisadi Teşebbüsleri ve Özelleştirme, İzmir.

Aktan, C. C. \& DiLEYici, D. (2005). “Altyapı Reformu: Altyapı Hizmetlerinin Sunumu ve Finansmanında Yeni Trendler-Alternatif Yöntemler", Altyapı Ekonomisi, Altyapı Hizmetlerinde Serbestleştirme ve Özelleştirme, (Ed.) Aktan, C.C., Dileyici, D. \& Vural, i. Y., Seçkin Yayıncılık, Ankara, 43-63.

Aslan C. \& Duarte, D. (2014). "How Do Countries Measure, Manage, And Monitor Fiscal Risks Generated By Public-Private Partnerships? Chile, Peru, South Africa, Turkey" World Bank Policy Research Working Paper, No. WPS7041.

Asian Development Bank. (2008). Public-Private Partnership Handbook, https://www.adb.org/sites/default/files/institutional-document/31484/publicprivate-partnership.pdf, (07.11.2019).

Ataay, F. (2007). Neoliberalizm ve Devletin Yeniden Yapılandırılması, De Ki Basım Yayım, Ankara.

Balcı, A. (2005). Kamu Hizmetleri ve Yerinden Yönetim, Sağlık Hizmeti Sunumunun Yeniden Yapılandırılması, Atlas Yayın Dağıtım, Ankara.

Baylıss, K. (2009). “Özelleştirme Teorisi ve Uygulaması, Kalkınma Bağlamında Politika Evriminin Eleştirel Bir Analizi", Neoliberal Küreselleşme ve Kalkınma Seçme Yazılar, (Der. ve Yay. Haz.) Şenses, F., Illetişim Yayınları, İstanbul, 545-572.

Boz, S. S. (2013). "Kamu Özel İşbirliği (PPP) Modeli”, Inönü Üniversitesi Hukuk Fakültesi Dergisi, 4(2), 277-332.

Bulutoğlu, K. (2008). Kamu Ekonomisi, 7. Baskı, Maliye ve Hukuk Yayınları, İstanbul.

Bülbül, D. \& Ertürk Atabey, S. (2010). "Türkiye'de Koşullu Yükümlülüklerin Kamu Finansman Açıkları Üzerine Etkileri", Sosyo Ekonomi Dergisi, 1, 61-78.

Chinyio, E. \& Gameson, R. (2009). "Private Finance Initiative in Use", Policy, Management and Finance of Public-Private Partnerships, (Ed.) Akıntoye, A. \& Beck, M., Blackwell Publishing, 3-26.

Cour Des Comptes Europeenne,(2018). Les Partenariats Public-Privé dans I'UE: de Multiples Insuffisances et des Avantages Limités, Rapport Spécial. https://www.eca.europa.eu/Lists/ECADocuments/SR18_09/SR_PPP_FR.pdf, (24.09.2019)

Çakır, M. K. (2016). 6428 Sayılı Kanuna Göre Kamu Özel İşbirliği Kavramı ve Yeni Bir Model: Yap Kirala Devret, Seçkin Yayıncılık, Ankara.

Çerçi, A. (2011). "Kamu Özel İşbirlikleri (Public Private Partnerships-PPP) Modeller, Riskler ve Finansman", Kalkınma, 59, 10-28.

Edizdoğan, N. \& Çetinkaya, Ö. (2010). Kamu Bütçesi, Ekin Basım Yayın Dağıtım, Bursa. 
Emek, U. (2009a). “Karşılaşmalı Perspektiften Kamu Özel İşbirlikleri: Avrupa Topluluğu ve Türkiye", Rekabet Dergisi, 10(1), 7-53.

Emek, U. (2009b). “Türkiye'de Altyapı Hizmetlerinin Özel Sektöre Gördürülmesi: Neden, Ne Zaman, Nasıl?", iktisat, işletme ve Finans; 24(284), 9-42.

EPSU (Avrupa Kamu Hizmetleri Federasyonu), (2004). Avrupa Entegrasyonu: Sosyal Diyalogu Geliştirmek ve Yüksek Kaliteli Kamu Hizmetlerini Savunmak, Avrupa Eğitimcileri El Kitabı, Avrupa Komisyonu Yayını.

Erdem E. (2015). "Sağlık Hizmetlerinde Kamu Özel Ortaklığı Modelinin Kamu Maliyesi Etkileri”, Yüksek Lisans Tezi, Dokuz Eylül Üniversitesi Sosyal Bilimler Enstitüsü, İzmir.

Ersöz, M. (2010). “Avrupa Birliği ve Türk Hukuku Işığında Public Private Partnership Uygulamaları", Yüksek Lisans Tezi, Marmara Üniversitesi Sosyal Bilimler Enstitüsü.

European Commission (2003). Guidelines For Successful Public-Private Partnerships, https://ec.europa.eu/regional_policy/sources/docgener/guides/ppp_en.pdf, (25.09.2019).

Göküş, M. (2011). Kamu Hizmeti-Kuram Politika Uygulama, Çizgi Kitabevi, Ankara.

Grımsey, D. \& LewIs, M. K. (2004). Public Private Partnerships, The Worldwide Revolution in Infrastructure Provision and Project Finance, Edward Elgar Publishing, UK.

Güzelsarı, S. (2013). "Kamu Özel Ortaklıkları Üzerine Eleştirel Bir Değerlendirme”, Kriz ve Türkiye, Aşınan Teoriler, (Ed.) Balseven, H. \& Ercan, F., Phoenix Yayınları, Ankara, 313-361.

Hemmıng, R. (2006). "Public-Private Partnerships, Government Guarantees, and Fiscal Risk", International Monetary Fund Washington DC, 1-14. http://www.eib.org/epec/, (25.09.2019).

Kamu Özel İşbirliği Özel îhtisas Komisyonu (2018). 11. Kalkınma Planı (2019-2023) Kamu Özel Iş̧birliği Özel Ihtisas Komisyonu Ön Raporu, Ankara.

Karahanoğulları, O. (2011). "Kamu Hizmetleri Piyasa İlişkisinde Dördüncü Tip: Eksik İmtiyaz (Kamu Özel Ortaklığı)", Ankara Üniversitesi SBF Dergisi, 66(3), 177-215

Karasu, K. (2011). "Sağlık Hizmetlerinin Örgütlenmesinde Kamu-Özel Ortaklığı”, Ankara Üniversitesi Siyasal Bilgiler Fakültesi Dergisi, 66(3), 217-262.

Kepenek, Y. (1990). Gelişimi, Sorunları ve Özelleştirilmeleriyle Türkiye'de Kamu Iktisadi Teşebbüsleri, 100 Soruda Serisi, Gerçek Yayınevi, İstanbul.

Kesik, A. (2012). "Kamu Hizmetlerinin Sunulmasında Kamu-Özel Sektör Ortak Girişimciliği (PPP)", "Yeni" Maliye, Değişim Çağında Kamu Maliyesi: Yeni Trendler, Yeni Paradigmalar, Yeni Öğretiler, Yeni Perspektifler, (Ed.) Aktan, C.C., Kesik, A. \& Dileyici, D., Ankara, T.C. Maliye Bakanlığı Strateji ve Geliştirme Başkanlığı Yayın No: 2012/420, 703-708. 
Keskin, B. (2005). "Kamu Hizmetinin Görülmesine İlişkin Sözleşmeler ve Bu Sözleşmelerden Doğan Uyuşmazlıkların Tahkim Yoluyla Çözümü", Doktora Tezi, Ankara Üniversitesi Sosyal Bilimler Enstitüsü, Ankara.

Kılıçaslan, H. (2017). Devletin Değişen Rolü ve Kamu Özel İşbirliği, Savaş Yayınevi Ankara.

Kirmanoğlu, H. (2019). Kamu Ekonomisi Analizi, 7. Baskı, Beta Basım Yayım Dağıtım, İstanbul.

Kovancılar, B., Miynat, M. \& Bursalıoğlu, S. (2007). Kamu Maliyesinde Küresel Değişimler, Gazi Kitabevi, Ankara.

Köstekçi, A. (2017). “Kamu ve Özel Sektör Ortaklıkları: Dünyada ve Türkiye'de Yaşanan Gelişmeler", Güncel Gelişmeler Perspektifinden Kamu Maliyesinde Seçme Konular, (Ed.) Yıldız, F. \& Tuncer, G., Savaş Yayınevi, Ankara, 309-338.

Kulaksız, S. \& Küçükkocaoğlu, G. (2019). “Kamu Hizmet Tedarik Yönteminin Seçilmesinde Yatırımın Değeri Analizi: Bir Hastane Projesi Üzerine Uygulanması", Muhasebe ve Bilim Dünyası Dergisi, 21(1), 197-227.

Mutluer, M. K., Öner, E. \& Kesik, A. (2007). Teoride ve Uygulamada Kamu Maliyesi, İstanbul Bilgi Üniversitesi Yayınları, İstanbul.

Memiş, D. A., Karadağ, V. G. \& Bingöl, H. (2012). "Kredi Riski Yönetimi”, Hazine işlemleri ve Çağdaş Hazine Yönetimi, (Ed.) Cangöz, M. C. \& Balıbek, E., Seçkin Yayıncilık, Ankara, 141-168.

Polackova, H, (1998). "Contingent Government Liabilities: A Hidden Risk For Fiscal Stability", The World Bank, Policy Research Working Paper, No. 1989.

Sönmez, M. (2018). "Sermaye Birikimi, Kamu-Özel İşbirliği ve Şehir Hastaneleri", Türkiye'de Sağlıkta Kamu-Özel Ortaklığı Şehir Hastaneleri, (Der.) Pala, K., Illetişim Yayınları, İstanbul, 55-70.

Şahin, M. \& Uysal, Ö. (2008). Kamu Ekonomisi Perspektifinden Kamu Özel Sektör Ortaklıkları, Ekin Basım Yayın Dağıtım, Bursa.

Şahin, M. \& Uysal, Ö. (2012). “Kamu Maliyesine Etkileri Açısından Kamu Özel Sektör Ortaklıkları Üzerine Bir Değerlendirme”, Maliye Dergisi, 162, 155-174.

Şenyüz, D. (1996). Yap-Işslet-Devret Sözleşmesi ve Tarafların Vergiler Karşısındaki Durumu, Yaklaşım Yayınları, Ankara.

T.C. Kalkınma Bakanlığı. (2014). Kamu Özel Işbirliği Özel ihtisas Komisyon Raporu, Onuncu Kalkınma Planı: 2014-2018, Ankara.

T.C. Kalkınma Bakanlığı. (2015). Kamu Özel İşbirliği Mevzuatı, Yatırım Programlama İzleme ve Değerlendirme Genel Müdürlüğü, Ankara.

T.C. Kalkınma Bakanlığı. (2016). Dünyada ve Türkiye'de Kamu Özel İşbirliği Uygulamalarına iliş̧kin Gelişmeler 2015, Yatırım Programlama İzleme ve Değerlendirme Genel Müdürlüğü, Ankara. 
T.C. Strateji ve Bütçe Başkanlığı. (2019). Kamu Özel İşbirliği Raporu 2018, Sektörler ve Kamu Yatırımları Genel Müdürlüğü, Ankara.

T.C. Maliye Bakanlığı. (2010). Kamu Özel İşbirlikleri ve Topluluk Hukukunda Kamu ihaleleri ve Imtiyazlarına ilişkin Yeşil Kitap (Gayri Resmi Çeviri).

Teker, S., Teker, D. \& Çimen, M. (2013). “Ulaştırma Projeleri Finansmanı İinin Bir Model Önerisi: Kamu Özel Sektör Ortaklığı Ile Bir Model Önerisi”, İsletme Araştırmaları Dergisi, 5(1), 116-129.

Tokatlıoğlu, M. (2004). Avrupa Birliği'nde Maliye Politikası ve Türkiye Açısından Bir Değerlendirme, Alfa Aktüel Yayınları, İstanbul.

Tokatlığlu, M. (2005). Küreselleşme ve Kamu Hizmetleri, Alfa Aktüel Yayınları, İstanbul.

Tokatlığlu, M. (2017). Fayda Maliyet Analizi, 2. Baskı, Ekin Kitabevi Basım Yayın, Bursa.

Toker, Ç. (2018). "Bütçeyi Hasta Eden Bir Sağlık Modeli: Şehir Hastaneleri”, Türkiye'de Sağlıkta Kamu-Özel Ortaklığı Şehir Hastaneleri, (Der.) Pala, K., İletişim Yayınları, İstanbul, 249-259.

Tunç, G. \& Özsaraç, E. (2015). “Türkiye'deki Kamu Özel İşbirliği Modelinin Iyileştirilmesine Ait Öneriler", 3. Deprem Mühendisliği ve Sismoloji Konferansı, 14-16 Ekim 2015, Dokuz Eylül Üniversitesi.

Yerlikaya, G. K. (2003). "Türkiye'de Yap İşlet Devret Modeli ve Kamu Borçlanması, ", Türkiye'de Kamu Borçlanması (Ekonomik ve Sosyal Etkileri, Beklentiler), 13. Türkiye Maliye Sempozyumu, 12-16 Mayıs 2003-Girne, Marmara Üniversitesi Maliye Araştırma ve Uygulama Merkezi Yayını, İstanbul, 419-447.

Van Thiel, S. \& Pollitt, C. (2007). "New Public Manager in Europe: Changes and Trends" New Public Management in Europe: Adaptation and Alternatives, Palgrave Macmiller.

Yescombe, E.R. (2007). Public-Private Partnerships Principles of Policy and Finance, Elsevier Finance, London.

Yusufoğlu, A. (2017). "Kamu Özel Ortaklığı Projelerinde Koşullu Yükümlülükler ve Mali Riskler: Avrasya Tüneli, Osmangazi ve Yavuz Sultan Selim Köprüleri Üzerine Bir Değerlendirme", Gazi Üniversitesi iktisadi ve Idari Bilimler Fakültesi Dergisi-Gazi Akademi Genç Sosyal Bilimciler Sempozyumu 2017 Özel Sayısı, 156-174.

https://ppiaf.org/about-us, (25.09.2019).

http://www.sbb.gov.tr/kamu-ozel-isbirligi-projelerinde-gelismeler/, (25.9.2019). 